\title{
The Urban Scale of Science and the Enlargement of Madrid (1851-1936)
}

\author{
Antonio Lafuente and Tiago Saraiva \\ Instituto de Historia, CSIC
}

"Tout récit est un récit de voyage, - une pratique de l'espace" M. de Certeau, L'invention du quotidien, (1990, l: 171)

\begin{abstract}
During the Enlightenment Madrid scientific institutions such as the Botanical Garden or the Natural History Museum served the demands of court ornament as well as colonial efficiency. They were landmarks of new urbanism and new science. In the XIX ${ }^{\text {th }}$ Century engineers and hygienists shifted from empire to the city. The relevance of their know-how was now certified by their capacity to solve the city problems. They had to bring water, design urban expansion and fight epidemics. Once again the sites from which these new actors reformed the city were heterotopias, symbols of the promised metropolis: new monuments both by their architecture and their noble function as scientific institutions.

All these local concerns were to be set aside by a new scientific community emerging in Madrid in the first decade of the XXth century. A group of physicists, chemists and biologists in search of international recognition, formed a new scientific campus on the outskirts of the city. The rationalism of their buildings was the best symbol of the new scientific culture of precision. A change of architectures which also meant a change of cultures. Our aim is to recover a lost sense of the city by placing ourselves at the beginning of the process of urban production. We hope that such a focus will reveal the fundamental role of scientific activity in the definition of the urban spaces.
\end{abstract}

Keywords: Urban expansion, science and the city, heterotopias, hygienism, civil engineers

Spaces are produced and cities are built as artefacts needing the invisible combination of a innumerable human and non-human actors, configuring the network which connects the local to that which has no location: places with flows, or buildings with symbols (Latour, 1998; Lefevre, 1974). For the object of this paper is to show the city as the subject and the object of a great experiment, its transformation into the capital of a modern state, leaving behind its former condition as the seat of the court.

Madrid, we argue, became an experimental laboratory where machines and experts objectivised problems, gathered data and drew up plans of action. It was not however just a work place, but also a patient prostrated on the operating table, on whom the engineers wielded their 
relentless scalpels. We talk here about "Big Science" in nineteenth-century Madrid. Both the scale of the operations and the number of people involved, as well as the public repercussions or the variety of technologies used, call into question the theory that this phenomenon is exclusive to the twentieth century ${ }^{1}$.

Naturally, to reach such a conclusion we stop regarding scientific activities as a combination of individual contributions made in separate specialities. We are interested here in the practices of science and in following the steps of the actors to show the simultaneity of two movements: firstly, that which links thoughts to a specific place, transforming abstract ideas into spatial experiences; and secondly, that which breaks objects down into tiny fragments suitable for the laboratory ${ }^{2}$. In our case, the city was the object to be dominated as well as the sentient subject, for every mark on its body engendered a body of analysts who argued about the extent of the change. It was a public debate, affecting all aspects of city life, from drains to transport and from public and private hygiene to the layout and naming of streets. Never before had public affairs -res publica-, both as justificatory rhetoric and as a professional practice, been so important. ${ }^{3}$

1 On Big Science see Capshew \& Rader (1992) and Galison (1992). For a discussion on the application of the concept for several contexts see Westfall (2003) and Lafuente \& Saraiva (2001)

2 After Owen Hannaway published his seminal essay on chemistry laboratories in early modern Europe (Hannaway, 1986), the place of knowledge production became a privileged subject for Science Studies. There is now a wide international literature dedicated to the located character of science. The works of Shapin (1988), Golinski (1998) Gooday (1998), Galison \& Thompson (1999) or Kohler (2002) are of particular relevance. However, the way of treating space in that literature is, we think, quite different from ours: they show a great concern for the place of science, but on the other hand they are not much interested in the production of space itself. Shapin (1988) for example explains very well how the ideas about space distribution (private/public) in seventeenth century London were essential to the way Boyle and Hooke produced and communicated experiments. But we have no information, and that is not Shapin's aim, on the way science itself contributed to the Londoners experience of space. Thus space is perceived as something preexistent, something that is already there and which influences or reveals the nature of science production. Our paper instead has more to do with science production as production of space experience, or to be more concrete, as production of urban experience. Not even the volume dedicated to "The Place of Knowledge", edited by Ophir, Shapin and Shaffer (1991) was able to bring together both movements to which we refer to in the text. For example, the contribution by Bill Hillier and Alan Penn devoted to the importance of the organization of the laboratory space, is in sharp contrast with the article by Jacques Revel dedicated to the knowledge of the territory. For a similar concern for putting science on the city map see Inkster (1977) and Forgan \& Gooday (1996).

3 For general discussion on the topic of science as public culture and the import of the Habermasian Public Sphere to Science Studies see Cooter \& Pumfrey (1994). A more recent perspective connecting with the literature on civil society in Broman (2002). BensaudeVincent (2000) offers a provocative French version of the history of the complicated relationship between science and the public. An overview of the same theme for the Spanish context in Lafuente \& Saraiva (2002). 
The outlook is promising, for the scientific disciplines put into circulation were at the same time creating the channels of communication. Even some of the architectural landmarks with which scientists hoped to lend dignity to the capital were also displays of technical prowess and, sometimes, the seat of their own activities. They were built as heterotopias since they show the disappearing face of the city and advocate what it promised to become instead (Foucault, 2001). But they may also be considered as advertising campaigns for the newly-emerging disciplines. By going back to the beginning of the process of urban transformation we have been able to understand the symbolic and visual importance of certain buildings, erected on open ground and forming a frontier between styles of architecture and cultures. And indeed, they should be considered as fragments of a temple and as parts of a machine, as the machinery of change and as intimations of the change of machinery.

\section{Sience as res publica}

During the second half of the eighteenth century, Spanish science recorded a rate of growth which can almost be described as spectacular (Lafuente \& Peset, 1988). And there is no doubt that an extremely high proportion of scientific activity during the Enlightenment was linked to Madrid, both in its condition of royal capital and as the centre of an empire. Both terms, court and metropolis, are crucial, and we can understand little of the science of the period without emphasising the need for courtly 


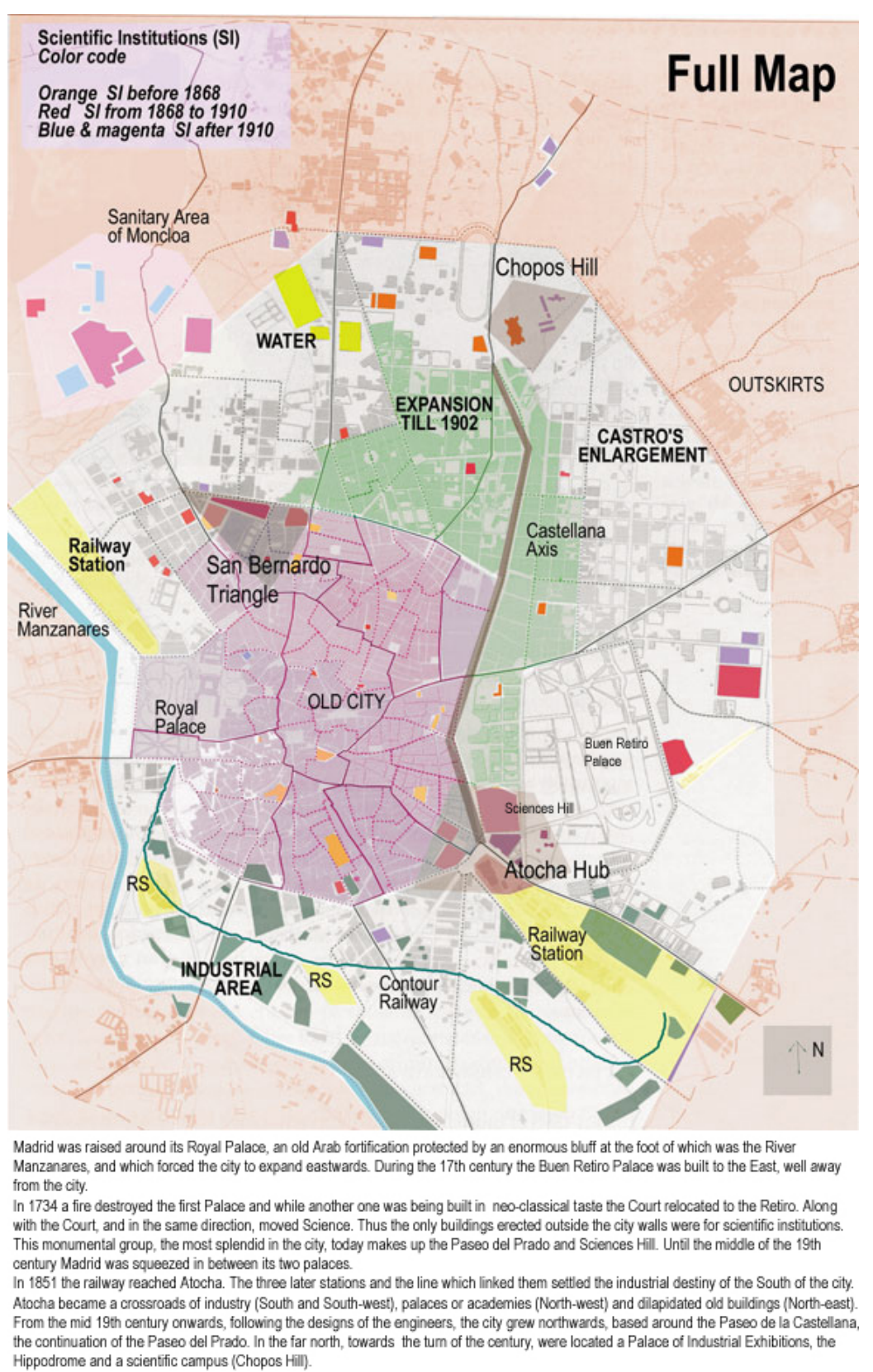

\section{Scientific institutions and the expansion of Madrid}

adornment

and

colonial efficiency

which were the basis

of the main body of

politics associated

with the financing,

patronage and

legitimacy of

scientific

undertakings ${ }^{4}$. Much

has been written

about the botanical,

hydrographic,

mineralogical and

sanitary expeditions

to America, an

initiative which left

the Court with

several tons of

papers and various

centres such as the

Royal Botanical

Garden, the Natural

History Museum, the

Royal Pharmacy, the

Hydrographic

Collection or the

Royal Astronomic

Observatory (Lafuente \& López-Ocón, 1996). But we cannot attempt to understand their full extent unless we see these new institutions as part of the city, unless we value their importance as architectural or urban landmarks (Lafuente, 1998).

4 There is a wide international literature dedicated to science and the court, for example, Biagioli (1993), Moran (1991), or Findlen (1993). For the relation between science and the colonial enterprise see the collective volume edited by MacLeod (2000), namely the paper by McClellan III \& Regourd (2000). For discussion of the transition from the model of courtoriented science to a more bourgeois form in Eighteenth-Century England see Walters (1997). 
The expansion of science was closely linked to that of the city and therefore, whatever assessment we may make of those scientists and their books, we must acknowledge that the opening out of the Paseo del Prado and the use of the hill between the old city wall and the Buen Retiro Palace for scientific installations were decisive events in the city's history. The first aim was simply to widen the public space by placing fashionable boulevards where once stood the city walls. But by 1780 the Paseo del Prado was also to become an area devoted to cultural ends. The location of the new projected scientific buildings in such an elegant site reveals how scientists were earning public credit for the renewal of the monarchy's image. The court architect Juan de Villanueva understood the challenge of providing Madrid with magnificent new buildings and designed a large-scale urban operation which included the Royal Botanical Garden, the Royal Observatory and the Academy of Sciences. This set of institutions formed "Sciences Hill". And we are not only talking about the exceptional architecture with which Villanueva opened the court out towards the East, but also of town planning and therefore of the engineering needed to build the drainage, infrastructures and communications (Sambricio, 1998).

So we can turn the argument on its head and state that the enlargement of the city also pushed that of science. This is an important point whose value was to become paramount during the nineteenth century and which, among other consequences, was to act as the motive force for scientific and technical activities in other urban centres in the peninsula. Science would thus cease to be the virtually exclusive property of the Court, enabling scientists to extend their range of influence, even when the principal object of their concern became the capital, or rather the cities. The Empire was no longer the focus of initiatives in scientific policies, which began to move towards the city. The old hegemony of botanists, astronomers and architects began to decline and to give way to new players, chief among whom were the professors, the doctor-surgeons and the engineers. The city, meanwhile, was both close at hand and open, and was therefore the scene of the conflict. Debates were public, as were the places where the arguments took place. The press and the café were also scenes of learning, sharing with specialised journals and academies the function of building authority. 
For some decades, Madrid, the city which concentrated all the defects of its monarchy ${ }^{5}$ and attracted such cutting descriptions as affected, rapacious, idle or unfinished, was the object of important debates and subject to great transformations. And it emerged from its lethargy to the rhythm of a certain consensus, which would finally become the dominant shared ideology: hygienism, a movement which was ostensibly purely sanitary, but which formed the backbone of a whole collection of discursive practices ranging from those of a preventative nature to those on the nature of policing. The subject matter covered everything, from private life to mental health, including drainage, drinking water supplies or the transport network. ${ }^{6}$ Making cities hygienic implied the transformation of the life of their inhabitants, it meant inventing new types of civic spirit since, in the words of the militant professor of Medicine at Barcelona, Rafael Rodrigues Méndez, “...hygiene in its broadest sense encompasses the whole universe" (Alcaide González, 1999b). Some data are very telling, and perhaps the most spectacular is the figure of 1309 legal provisions seeking to regulate this domain between 1841 and 1860. And between 1808 and 1936 were printed 1738 books and 125 journals about public hygiene ${ }^{7}$. And finally these questions introduced two new public protagonists who would fight for domination of the subject of hygiene: doctors and engineers, two groups who would make use of the press to mobilise public opinion and who would be characterised by their ability to translate into technical terms the great social and cultural contradictions which demographic growth entailed. ${ }^{8}$

\footnotetext{
5 During the first half of the nineteenth century the Spanish monarchy became into a a discredited institution, with no court to symbolise its grandeur in a country beset by debt (Prados de la Escosura, 1988), civil war (Artola, 1973) and popular uprisings (Julia, 1997). The backwardness of the kingdom was evident, ruined by the absolutist rule of Fernando VII, who accessed to the throne in 1814. Whereas in France Louis XVIII, another restored monarch, accepted a "balanced" constitution, Fernando rejected out of hand any form of constitution. In particular nineteenth-century historiographers depicted the so-called "ominous decade" of 1823-1833 as a period of unbridled clerical reaction, and the prime reason for Spain's backwardness.

6 For the rise of similar concerns about the poor's urban livng conditions in England and France, see for example Hamlin (1998) and La Berge (2002)

7 In relative terms, this higienist literature represented 27\% (medical books) and $14 \%$ (medical journals) respectively, since overall figures for the period were of 7333 books and 920 periodicals, of which only 13 lasted more than 13 years. See, Alcaide González (1999a) 8 For discussion in the French context on these two groups that took the city in their hands see Barles (1999).
} 
Madrid was without a university by the eighteenth century -like

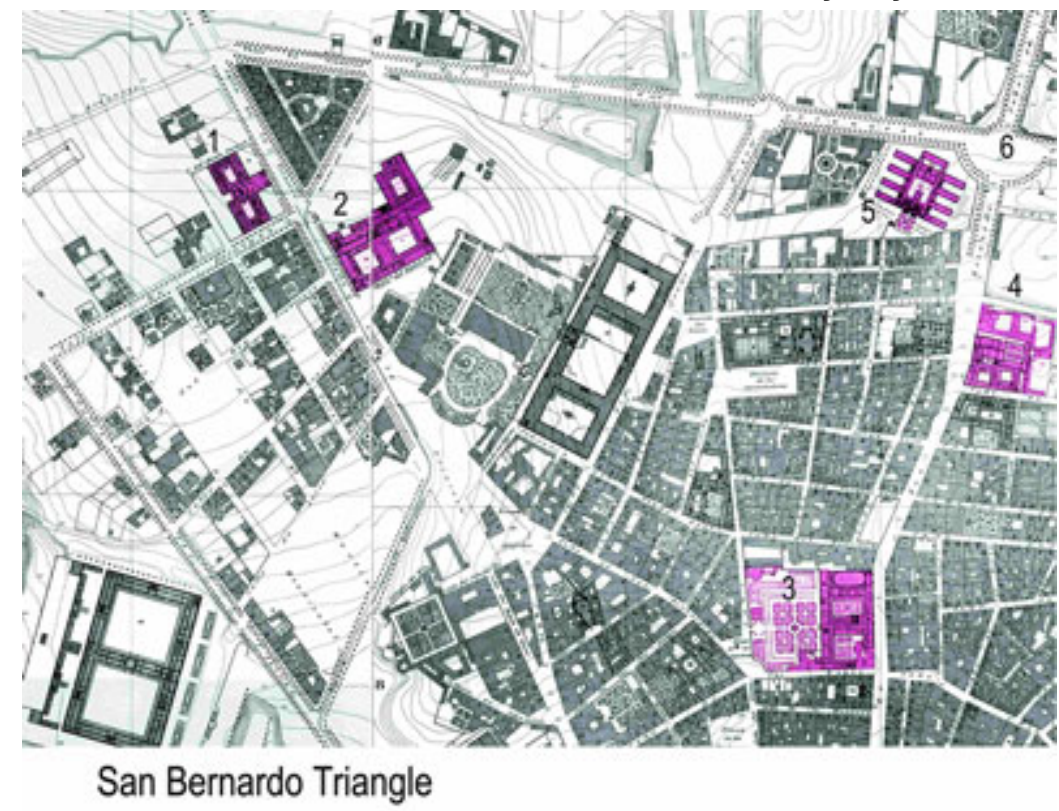

1 Buen Suceso Hospital 2 Military Hospital 3 University (main building)

4 Salesas Convent (University) 5 Princesa Hospital 6 San Bernardo Sq.

London, Berlin or

Lisbon- (Pyenson

and

Sheets

Pyenson, 1999:

48-73) 9 . Nor did it have an Academy of

Sciences,

a

peculiarity which

set it apart from the

other European

capitals. Now, well

into the nineteenth

century, it was

impossible to

The San Bernardo triangle

The area of San Bernardo (6), the northern frontier skirted by open fields, became the focal point of academic activity. A triangle where, as well as the University ( 3 and 4 ) and the Princesa Hospital (5), were to be found the military scientific institutions centred around the three courtyards of the Conde Duque Barracks (in the centre of the triangle): the Buen Suceso Hospital (1), the Health Laboratory (2), the Hygiene laboratory (2) and the Engineering Laboratory.

conceive of any plan for

constructing a

nation which was

not based on a capital boasting establishments such as these ${ }^{10}$. The normal development of the life of a country demanded an army of lawyers and doctors who, after the weakening and disentailment of the Church (the seizure of its property), would take the orders issued by the government to the furthest corners of the land. This at least was the theory which enabled the people of the capital to usurp the University of Alcalá, the Complutense, founded by the all-powerful Cardinal Cisneros in 1499. The Ministerio de la Gobernación took the decision to house it in separate buildings scattered around the city all of them former property of the Church. The main building was installed in the Northwest corner of Madrid, in the old Jesuit Noviciate of Calle San Bernardo ${ }^{11}$. The Faculty of Medicine was located at

9 For national cases, see McClelland (1980), Ardwell (1972), Russell (1983), Shin (1979). For
the changing relationship between city and the university, see Brockliss (2000).
10 Until the middle of the century university science teaching, except for medical subjects,
was not independent. The Pidal Plan (1845) created the science section within the Faculty of
Philosophy. Twelve years later, the Moyano law (1857) founded the Faculties of Science. The
new Engineering Schools were set up between 1834 and 1855 , although their permanence
was not guaranteed until 1866 . Finally, after the establishment of a short-lived and
precarious Academy of Natural Sciences (1834-43), the Royal Academy of Exact, Physical and
Natural Sciences was founded in 1847. See, López-Piñero (1992).
11 It also occupied other premises, such as the Salesas Convent or the San Isidoro School,
the former Imperial College of the Jesuits, near Plaza Mayor, an urban landmark that 
the opposite edge of the city, in the Southeast in Atocha in the historical sanitary nucleus dominated by the huge mass of the General Hospital built in the Eighteenth century (and where nowadays is located the Reina Sofía Museum of Contemporary Art). The Sciences Hill institutions (the Botanical Garden, the Observatory and the Natural History Museum) were also incorporated into a University which brought together several buildings, and which under the same bureaucratic patron devoured establishments founded in the eighteenth century as government agencies linked to imperial power (Baratas-Diaz, 1996). But there is one point of particular interest which we cannot forget, for the decision to occupy buildings within the confines of the city dealt a decisive blow to the plan to convert Sciences Hill next to the East wall of the city into a scientific campus for the court. In the middle of the century the expansion of science, contrary to what had been its distinguishing mark during the Enlightenment, did not bring with it

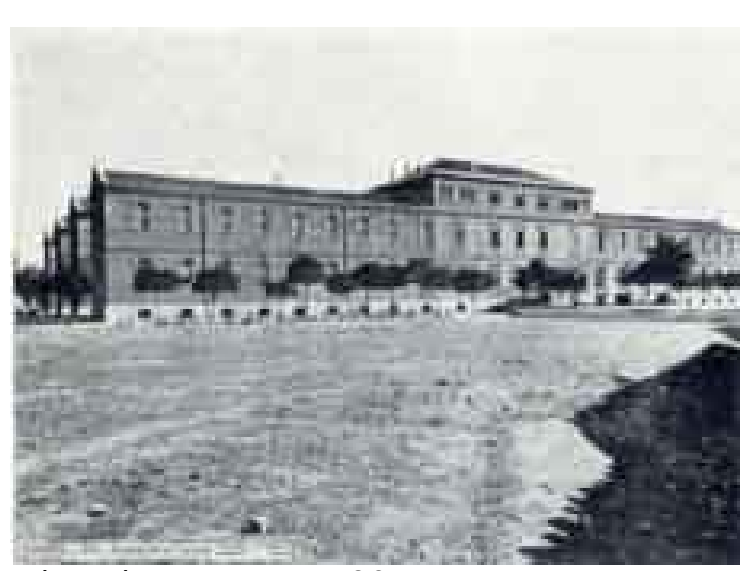

Photo by J. Laurent 1901

ImAge 1: Princesa Hospital (1852)

The main innovation in 19th-century hospital architecture was to provide the buildings with a structure of side wings, attached at right angles to a central area which controlled the flow of traffic and centralised services. Its location in the San Bernardo triangle, set among open fields, confirmed a twofold expansion: that of the city towards the north and that of medicine towards specialization. Thus while the fringes of the city were graced with an outstanding building, greater prestige was

bestowed on an activity which was more and more directed towards health-care and less and less to charitable works the opening up of the city, but simply the assignment of new functions to old buildings.

The latest developments in science in Madrid (see San Bernardo Triangle map) were emerging within a triangle in the northwest edge of the city, for in the next two decades, as well as the university premises and the new Princesa Hospital, we find the nucleus of military science establishments, which gravitated towards the Conde Duque Barracks: the Buen Suceso Hospital, the Military Health Laboratory, The Military Hygiene Laboratory, and the Laboratory of Military Engineers ${ }^{12}$.

Science, which under the reign of the House of Austria (16 $6^{\text {th }}$ and $17^{\text {th }}$ century) huddled round the Royal Palace at the western limits of Madrid and

constitutes the very center of all Hispanic Baroque Cities.

12 In 1914 the Spanish Association for the Progress of Sciences (founded at 1908) published a Report about Madrid research laboratories. Reading it we realized the existence of this dense area of military scientific institutions around the Conde Duque barracks (Reseña,1914). Unfortunately there is no serious work about this interesting cluster of institutions. 


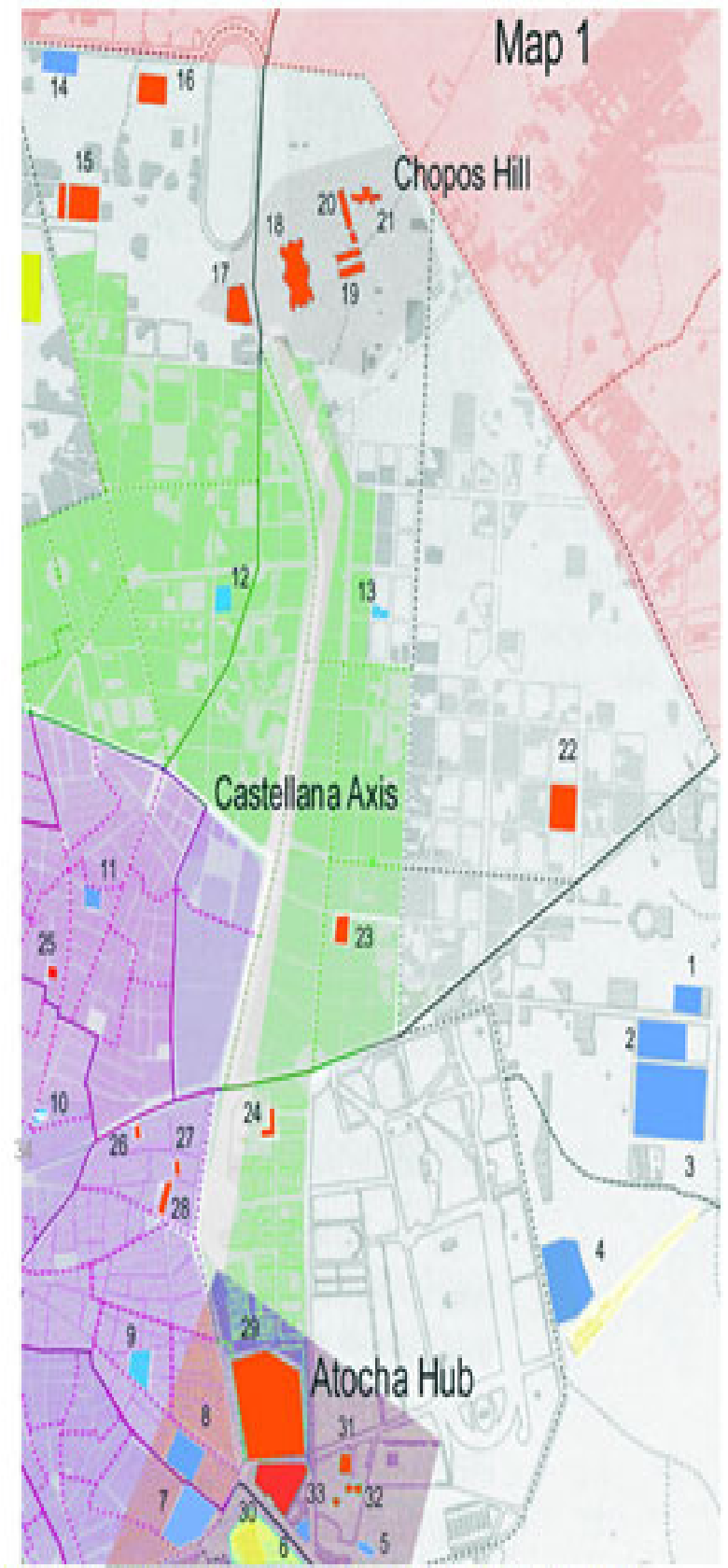

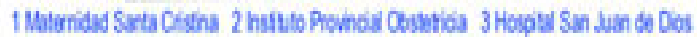

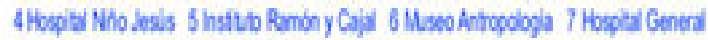

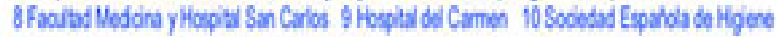

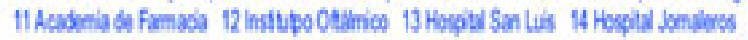
34 Reademia Musos Q iringica

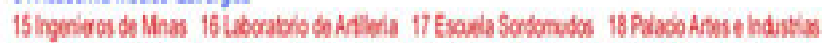

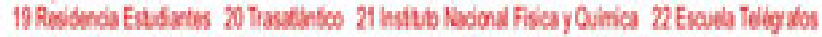

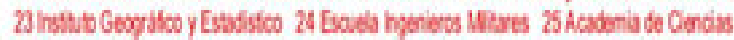

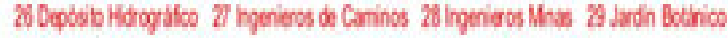

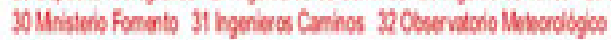

33 Oburviono Astonomico

The Castellana Axis: From Atocha Hub to Chopos Hill In the south the Atocha hub was dominated by those engineers who used the city as an experimental laboratory, giving it a rectangular plan, water and a quayside connected to the sea. To the north, next to the Hippodrome, there was a campus set well away from the noise and hurly-burly of the centre: a place of meditation. Two worlds, two cities: two ways of understanding science and two viewpoints from which to contemplate the city: one set among factories, the other among fields. Very much a symbol of changes to come. 
under the early Bourbons ( $18^{\text {th }}$ century) went off to the East to Sciences Hill, confirmed its drift towards the city outskirts during the nineteenth century (See Image 1).

Dispersion was one of the most marked characteristics of Spanish science at this time. But it was not the only one. The peregrinations of the scientific institutions around the city also had a structural nature. The Academy of Sciences, for example, was located in several standby buildings in the surroundings of the Royal Palace before it found a permanent and proper home in 1897 (Moreno-González, 1988: 432). And this problem not only affected academics: the Civil Engineers had to put up with six different locations until they at last managed to have their own building erected in 1889 ${ }^{13}$, and Mining Engineers had five until they received newly-built premises in $1893^{14}$.

From a glance at the plan of Madrid, we can see the tendency of science to concentrate in two centres from the end of the 1840's: the newest in the north-west, in the so-called San Bernardo triangle and, to the south-east, the legacy of the Enlightenment sanitary nucleus in the neighbourhood of Atocha. It is also quite clear that scientific institutions were less relevant and had more straitened circumstances the closer they came to the Royal Palace. Any way, they were nomad until they found a settled home. None of them was able to avoid a laborious trek around the city until winning the right to a building of their own.

\footnotetext{
13 The School of Civil Engineers, founded in 1802, was housed in the Buen Retiro Palace, next to the Machine Museum (1792). Although teaching was suspended in 1808 because of the war with the French, the models brought by Agustín Betancourt from Paris and displayed in the Museum were transferred to the Goyeneche Palace, seat of the Royal Academy of Fine Arts of San Fernando and, on the second floor, of the Natural History Museum. After a brief return to the battered Royal Palace they passed to the Buenavista Palace, until in 1813 they were housed in the Lujanes Tower, sharing the space with the Royal Madrilenian Society of Friends of the Country. The school functioned between 1821 and 1823, but was closed again. Reopened in 1834, it occupied the decrepit building of the Old Customs House. In 1847 we find them in Calle del Turco in a building which since 1799 had housed the Royal School of Chemistry of Madrid and, later, the Royal Conservatory of Arts (1824-1850) an institution which was moved off to the Trinidad Convent. In 1886, at last, it was decided to put up a new building, next to the Retiro at Calle Alfonso XII, and to which they moved for the year 1889/90. See Romeu de Armas (1990) and Sáenz-Ridruejo (1993).

14 The Mining Engineers fared no better. In 1825, the General Directorate of Mines was set up in a fourth-floor flat in Calle del Amor de Dios. The following year they moved to Calle del Lobo and four years later, in 1830, there was an improvement when they went to new premises very close to where the Civil Engineers were. And although teaching took place in all these locations, the school as such was not founded until 1835 in the premises of the Directorate General, but now occupying a whole block. A change of ownership of the building forced them to moove again to the old and tight № 8, Plaza Conde de Barajas. So they were not satisfied until the Ministry of Development authorised in 1884 the erection of Velázquez Bosco's building which they still have in Calle Ríos Rosas. See, Centenario (1977).
} 
The case of the Academies is particularly telling since they had their origins as private associations of dignitaries and scholars in pursuit of official approval and, after a period in which some, such as those of Medicine or Sciences, actually achieved responsibilities for the management of public health or the development of territorial policies, they ended up as a sort of hybrid between a lay sanctuary and a nineteenth-century athenaeum. Those who asked for better facilities, arguing that such claims reflected the recognition of the dignity of their knowledge and the necessary recognition of the Monarchy, were not far wrong. But the fact is that as the century passed they degenerated into tertulias, informal circles of distinguished men meeting in Cafés ${ }^{15}$.

Indeed, The Academy of Sciences saw its influence decline as the years went by. If we look at the origin of the first 36 academicians, we find that 20 of them were engineers or military men, no doubt the best allies to set up the venture (Torroja Menéndez, 1995) ${ }^{16}$. If we turn to the projects with which they were concerned, the most important are those related to the preparation of the topographic and geological map of Spain, a vital project for a country involved in a process of economic industrialisation and state centralisation. But it was not long before a special mechanism was set up: the Royal Commission of General Statistics (1856) was much more responsive to the government's orders and more efficient in carrying out its tasks ${ }^{17}$. It was not that projects were halted, nor that people were changed, but rather what had also happened to the Academy of Medicine: they were transferred to organisations which were more hierarchical and submissive to national politics.

When we say that the tertulia was the principal distinguishing mark of the academicians and practically the only channel for public acceptance of ideas, we do so absolutely without irony ${ }^{18}$. We have already seen the

15 The case of the Academy of Medicine seems typical. When it was created in 1732, among its responsibilities were hospital policy- including building- the fight against epidemics, medical training or testing of medicines; but in 1747 the policy functions were separated from the scientific and, of course, the Academy lost the power it had acquired and was reduced to a purely consultative body.

16 Moreno (1988: 437) concludes that at the end the main function of the Academy was to circulate textbooks or popular science books.

17 On the involvement of the Academy in the project of the topographical map of Spain $(1: 50,000)$ and land registry projects, see Urteaga \& Nadal, 2001)

18 To be sure of the cultural importance of Nineteenth-Century tertulias one only has to look at the influence of the Scientific, Literary and Artistic Athenaeum of Madrid, founded in 1835, and which would soon be adopted as the privileged locale for debates about the ideas of the nineteenth century. A Liberal centre par excellence, it was the stage where the tension between popular culture and intellectuals or the conflict between Catholic morality and Positivist ethics was played out. It was not uncommon at the time for the most distinguished 
success of the medical press, especially that of the hygienists, a form of communication directly related to the tertulia and with the emergence of public opinion sensitive to scientific matters. We shall return to this point, but for now we would like to refer to the importance of newspapers and café society to the development of Spanish science in the nineteenth century. ${ }^{19}$ We shall not take up many lines with such a self-evident fact. It is enough to look, for example, at the journals published by the Academy of Sciences, and those promoted by Civil Engineers and Forestry Engineers (López-Ocón, 1997; Chastagnaret, 1975), all full of articles which we would now class as popular science and which, generally speaking, managed to combine corporate concerns with the aspirations to progress which were taking root in the capital and whose sounding board was to be found in many of the most famous cafés frequented by doctors, engineers and men of letters ${ }^{20}$.

Science was becoming a public affair. And what is noteworthy is that, just as in the field of artistic creation where literature became confused with literary life, scientific matters were not only theories subject to the exchange of opinions, but they were there for all to see. It is not that the institutions had particular difficulty in establishing themselves as seats of learning, but rather that their supporters used the city, its cafés and newspapers, as well as the street itself, to make their presence felt and to

\footnotetext{
Spanish scientists to take the rostrum and to deliver lectures to great public acclaim For more on this institution, see Villacorta-Baños (1985) .

19 For esays on the relationship between press and science in several different national contexts see Bensaude Vincent \& Rasmussen (1997). Sheets-Pyenson (1985) is still worthwhile.

20 The Café Príncipe seems to have been the first to gain favour with doctors, and it was round its tables that the most distinguished Liberal doctors discussed the need to unify the health professions and championed the merger between the study of surgery and medicine. In the San Sebastián (founded in 1840) was founded a tertulia which might well be classed as an authentic lobby of Madrid hygienists. The Oriental, near the Academy of Medicine, was the meeting-place for two tertulias: one, before lunch, was for narrow-minded right wing doctors and the other, in the evening, centred on a group of the most progressive and cosmopolitan professors (Alvarez-Sierra 1966). There are many examples, but none more persuasive than that of Santiago Ramón y Cajal, Nobel Prize-winner for Medicine in 1906 someone who could hardly be described as frivolous and who admitted that he had spent his youth between one café and another.

Santiago Ramón y Cajal (1852-1934) has no peer in the pantheon of Spanish scientists. His histological research, characterised by his original use of the techniques of staining, laid the foundations for the knowledge of the microanatomy of the nervous system, and in particular stimulated the theory of neurones, against Golgi's network theory. He described the structure of several nerve centres (spinal cord, cerebellum, retina...) and deduced fundamental physiological implications such as the orientation and direction of nerve stimulation. In 1902 international recognition of this work enabled him to set up in Madrid the Biological Investigations Laboratory, where he was able to develop his new lines of research devoted to the degeneration and regeneration of nerve tissue. In 1907 after winning the Nobel Prize he was elected President of the Junta para la Ampliación de Estudios (see below, fn 26), the body responsible for the modernisation of science in Spain. The bibliography on Cajal is huge, but we particularly recommend his autobiography (Ramon y Cajal, 1984). Also see, Baratas-Diaz (1997) and Rodriguez-Quiroga (2001).
} 


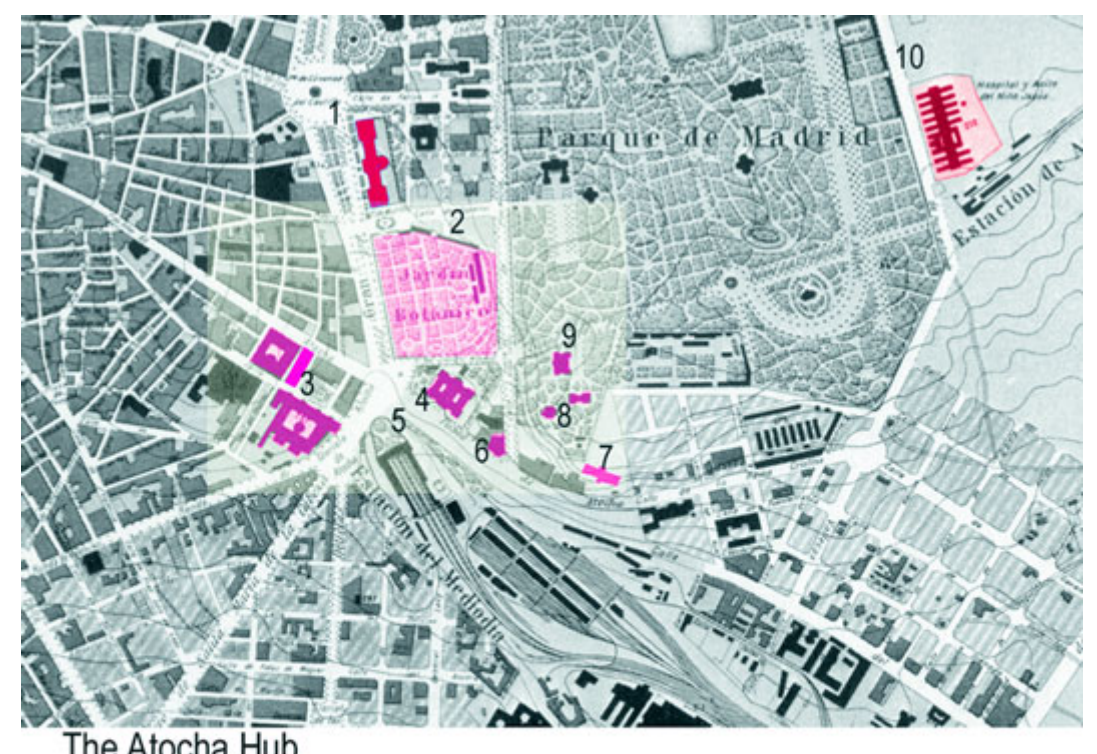

The Atocha Hub

1 Museum of Prado, first built for Academy of Sciences 2 Royal Botanical Garden 3 General Hospital and Faculty of Medicine 4 Ministry of Development 5 Atocha Railway Station 6 Museum of Anthropology 7 Cajal Institut 8 Astronomical Observatory 9 School of Civil Engineers 10 Niño Jesús Hospital

The concentration of institutions in Atocha created a very special scientifictechnical campus: Atocha, the gate to Madrid, was the entrance for passengers, goods and ideas. At the time it seemed to be the kingpin for the world of production and knowledge. achieve

broad

consensus on

the importance of their work and their goals. Science is to be found in the city, not only the city conjured up by plans but also that lived in its streets, since both preach the new power associated with knowledge, whether we consider the authoritarianism with which spaces and functions are designed, or the new architectural landmarks which transform it. And the opposite statement is also true, which says that we should look for the city in the science which maintains it, since for decades scientists and engineers living there were concerned with the fight against disease, the demolition of the city walls, the supply of water, the improvement of communications, the cleanliness of markets or the dissemination of their plans. Science was becoming urban, and the city wanted to become rational. Scientists were converted to public figures and politicians surrounded themselves with scholars and specialists. The nineteenth century was indeed the golden age of popularisation of science, in both directions, since ideas reached street level and the street was the main focus of the ideas.

Shopping arcades, as Walter Benjamin explained, became a symbol of the times. And Madrid hastened to copy this Parisian fashion. The most tangible was the presence of iron and glass as structural elements, but the important thing was the new historical figure they attracted: the flâneur, an anonymous passer-by among shop windows and arcades who projects his soul onto the objects on display (Buck-Morss, 1989). Iron was the material which symbolised the new age and the greatest challenge facing planners 
and architects. And the reason is simple: it fulfilled a double role: on the one hand it enabled the construction of great covered spaces to shelter the masses, and on the other it implanted in the city monumental forms which, unlike cathedrals or palace precincts, exchanged their religious or courtly identity for another more bourgeois and technological.

Madrid, said Mariano J. Larra ${ }^{21}$, was a city with too many people for the opera or the cafés, but not enough for the gardens. And of course, this is one of the wittier ways of addressing the old cliché lamenting the absence of a middle class or, as we say nowadays, of civil society. But our admiration for the form does not extend to the content. The point is that perhaps it is in these imposing iron gardens that we should look for people: the people who Ildefonso Cerdá 22 or Angel Fernández de los Ríos ${ }^{23}$ did in fact find. And we could add many more: circuses, pelota courts, markets, shopping arcades, exhibition halls or libraries.

They are all important, but at the end of the century we inevitably stop at Atocha station. Suffice it to recall that we are talking of an iron hall of 48 metres span, 27 metres high and 152 long. Indeed, the premises of this "port" of Madrid extended to the south of the ring road (the Rondas) and as far as the River Manzanares. Near the still fashionable Paseo del Prado the monumental factory of the Central Station was only rivalled by the enormous Ministry of Development ${ }^{24}$ : the House of Machines and the 21 Mariano José de Larra (1809-1837), novelist, playwright and poet, was particularly
appreciated for his theatre criticism, his political articles and his ironic accounts of Madrid
customs. If he began as an enthusiast of enlightened ideals, he was soon to adopt the
posture of disillusioned critic, faced with the difficulty of (as they said at that time)
Europeanising Spain. His suicide at the age of 28 for amorous reasons contributed to the
mythologisation of Larra as the Spanish romantic author par excellence.
22 Ildefonso Cerdá y Sunyer (1815-1876), civil engineer, was most notable for his ambitious
plan for the enlargement of Barcelona which he put into effect from 1860 onwards. His
original combination of hygienist and technical theories, giving equal importance to the
circulation of miasma and of traffic was embodied in his "General Theory of Town Planning
and the applications of its Principles and Tenets to the Improvement and Enlargement of
Barcelona" (1867), one of the first European essays devoted to considering the city in the
steam age.

23 A. Fernández de los Ríos (1821-1880), publicist, founder of several Madrid newspapers, most notably the daily Las Novedades with its high circulation and novel distribution system, and several magazines such as La Ilustración or El Museo Universal, famous for the quality of the engravings. Town planning was one of his pet subjects, and he never disengaged his political activity as a left-wing Liberal from his concerns for the improvement of Madrid. The two subjects combine in his writings, such as "El futuro Madrid: paseos mentales por la capital de España"(1868) or in the "Guía de Madrid: manual del madrileño y del forastero"(1876). For more on this fascinating character, see Bonet Correa (1989).

24 The enormous building housing the Ministry of Development (1893) was first projected as School of Arts and Crafts. But soon after the works started, the Ministry, which had the responsability of all education politics, changed its destiny in order to become Faculty of Sciences and Natural History Museum. However in 1893 the Ministry changed ideas once more and took the building as its own headquarters. Although in the nineteenth-century there was no coherent urban project for the area as the one of Sciences Hill in the eighteenth-century, it was clear that the Ministry saw it as a sort of scientific campus. The 
House of Engineers, both standing alone in a frontier zone waiting for urbanization (Aguilar-Civera, 1980). Two heterotopias promising a new Madrid and a new Spain built by engineers. And if we look at the map of 1900 (see Atocha Hub map), full of gaps which would later be filled, we notice that there is a visual relationship between those two monuments and a cluster of scientific institutions which, starting at Sciences Hill spreads until it takes over Atocha ${ }^{25}$. This entire area was a hub of communications and a nucleus of scientific activity. The scientific-technical buildings that stand out in this frontier landscape make up the identity of the site. It is no longer the courtesan space of Paseo del Prado and Sciences Hill. The engineers and their new monuments have taken possession of the noblest part of the city, and brought with them all the turmoil associated with Progress. And, as we have said, once the migration of science to the other side of the city wall, ever further from the Palace in the west, had been confirmed, a new collective drift began towards the north (see Map 1).

It is not that science was following the development of the city. This was never the pattern; rather it was the city which followed in the footsteps of science. At the far northern end of the Castellana, a frontier zone to which the Exhibition Palace of Arts and Industries and the Racetrack lent a festive and élitist atmosphere, the Mining, Industrial and Military Engineers had begun to install themselves. From 1910 onwards would arrive the National Museum of Natural Sciences and the Automatics and Physics Laboratories, created by the Junta de Ampliación de Estudios ${ }^{26}$ and directed by Leonardo Torres Quevedo ${ }^{27}$ and Blas Cabrera ${ }^{28}$, respectively. And again

several attempts to build new premises in the area for the Faculty of Sciences were always justified with the lack of free space in the centre of the city and the advantages of locating it near the Botanical Garden, the Observatory, the Civil Engineers School and the Faculty of Medicine. (Baratas Díaz, 1996: 190-192)

25 They were the Garden, the Observatory, the Meteorological Station, the new Civil Engineers School and the Anthropological Museum and, later, the imposing building constructed to house the Cajal Institute. On the other side of the Atocha roundabout, the General Hospital and the Faculty of Medicine, remained inside the old city limits.

26 La Junta para la Ampliación de Estudios (JAE) was set up in 1907. It was a body created in the image of the French École Practique des Hautes Études. As well as awarding scholarships to study abroad (particularly in France and Germany) the JAE combined several former scientific centres such as the Museum of Natural Sciences or the Biological Research Laboratory and other new laboratories such as Physiology, Automatics or Physics Research. (Sánchez Ron, 1988).

27 Leonardo Torres Quevedo (1852-1936), civil engineer, has a biography which resembles the plot of a novel by Jules Verne. His inventions include aerial transporters (like that crossing the Niagara Falls), algebra machines, mechanical chessplayers and dirigibles. His Automatics Laboratory was an important centre of the JAE, since it furnished a large part of the instruments needed by the other laboratories (Sánchez Ron, 1999).

28 Blas Cabrera y Felipe (1878-1945) was the principal driving force of Physics in Spain. In 1912, within the context of the JAE, he obtained finance for a stay in the laboratory of Peter Weiss in Zurich. As well as a researcher, he had an important role as a populariser of 
we have to take a map showing the changes in the second decade of the twentieth century in order to make clear what is now invisible: the visual relationship and thus the physical closeness established between institutions which had no other buildings surrounding them. And there is another point worthy of comment, since we are dealing with buildings with a double monumental role: first, they emerge magnificently out of open fields and second, they are dedicated to the fostering of knowledge.

Let us stop and look at the palace which Velázquez Bosco ${ }^{29}$ built for the Mining Engineers. After winning popular recognition with the successful mining exhibition held in 1883, Mining Engineers were finally honoured by the Ministry of Development with respectable premises, leaving behind rented houses and tight rooms. However they faced the opposition of the School of Civil Engineers which together with the Observatory refused their location in the Atocha Hub, arguing that mining experiences were too noisy and dangerous. They were then expelled to Calle Ríos Rosas, in the new expansion districts to the north of the old city. Few buildings better reflect the fact of being at once an urban landmark and a scientific landmark. Even today, it offers an opulence which would be multiplied a hundredfold if we could imagine it in the middle of abandoned plots of land, still far from the recently built water reservoir of the city. Madrid was not over-endowed with buildings which could rival this façade, covered with allegories and with its six Corinthian columns. The bold decoration of the exterior surrounds a square plan of extreme simplicity. On the corners are placed four slightly protruding wings which frame the façade. The floor at street level is set aside for purely educational functions, and is almost entirely occupied by the classrooms for the seven subjects, all painted in pastel colours and with folding chairs, following the pattern of the Polytechnic School of Berlin. Upstairs are the most elegant areas of the building: the library, the museum, the drawing studio and the meeting room. The meeting room, decorated with allegories on the ceiling, as well as the entrance staircase, made of iron with oak treads and bronze banisters, complete a ritualised

science, notably in his publications on relativity. In 1932 when the National Physics and Chemistry Institute was set up with finance from the Rockefeller Foundation, Cabrera was appointed director. After the Spanish Civil War, he went into exile in Mexico (Sánchez Ron, 1999: 213-218)

29 Ricardo Velázquez Bosco was one of the most prominent Nineteenth-Century Spanish architects. He projected several outstanding buildings in Madrid like those for the Ministry of Development, educational institutions or exhibitions palaces. He could be considered as the official architect of the Ministry always prone to lend his monumental fingerprint to the politicians initiatives (Velázquez Bosco, 1990). 
and symbolic whole, which combines the tradition of mosaic with the modernity of iron, national identity with technical progress, practical knowledge with the aesthetics of the palace, and the monumentality of the façade with the industrial functionality of the courtyard (Repullés Vargas, 1897; Navascués, 1973). Seen as an organic whole, the building works like a machine ready to cater for all aspects of the life of the engineer, from the care of his body in the gymnasium in the basement and his spirit in the ground-floor classrooms, to the training of his memory and movements in the museum and drawing studio on the first floor ${ }^{30}$.

If we now look at the ground plan of the Civil Engineers' new building in the Atocha area, we shall see similarities which are attributable to the corporate spirit which they shared with the Miners (Nueva, 1889). But we cannot talk about nineteenth-century engineers without mentioning their cult of discipline, more military than academic. The pupils, however, knew

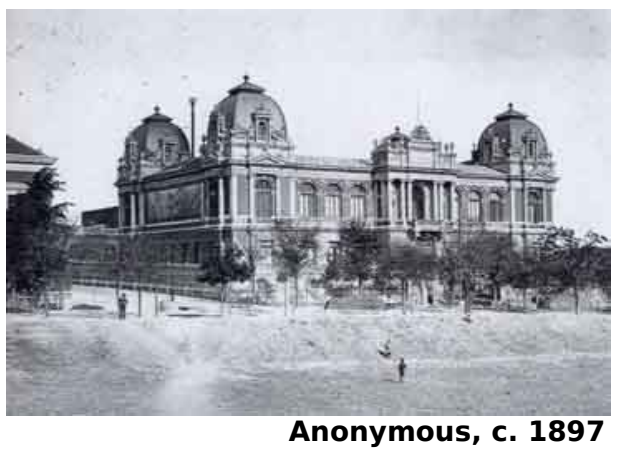

The Mining School (1893)

The new Palace constructed by the engineers in the poor suburbs of the city was the natural result of a long migration round the city begun in 1825 . They finally obtained this building after passing through five provisional locations. In 1883 the Mining Exhibition gave them the prestige they needed to acquire the splendid edifice designed by the architect Ricardo Velázquez Bosco. The building, one of the first in the area, was near the Hippodrome and the Palace of Arts and Industries. what they were letting themselves in for. In 1861, for example, 49 candidates were admitted of the 108 who applied, and only 19 finished their course (Saénz Ridruejo, 1993). The numbers are small and indicate the elitist character these bodies always had, as well as their talent, both scientific and propagandist, for presenting themselves before public opinion as having sole responsibility for the modernisation of the country. ${ }^{31}$

No one denies that the Mining School is an adornment to the city but, like all buildings, it belongs to its own age.

30 For a similar approach to scientific buildings layouts in the South Kensington area, see Forgan \& Gooday (1996).

31 Spanish Civil Engineers shared their elitist character with the French engineers of the École des Ponts et Chaussés. This institution worked as a truly inspiring model, for not only the founding fathers of the Spanish school were first taught at the Parisian École, but also because the textbooks were almost exclusively imported from France. Spanish students of civil engineering received an extensive theoretical training on subjects like mathematical analysis and descriptive geometry, which was perceived as a fundamental precondition in order to become a civil servant in the state's Corp of engineers. Following the French model these engineers were perceived as the technical arm of the State developing an ethos much similar to the military one (their official uniform even included a sword and was hardly distinguishable from an army costume). For French engineers see Picon (1992) and Belhoste et. al. (1995).For a discussion on the contrasting character of French and Anglo-American engineering see Kranakis (1997) 
There were many architects, however, who were quick to see it as a pretentious and artificial contrivance. Antonio Flórez was one of those who, scorning those ornamental passions, opted for a style of architecture which would neither conceal the structure nor disguise its function. The two blocks built in 1913 for the Residencia de Estudiantes (Students' Residence) may not be the paradigm of rationalism, but they do have a level-headed appearance which only shows off their simplicity of line and modesty of materials. There were fewer resources, but there was also a different approach to understanding culture and, consequently, architecture. Documents show that it was all planned with loving care. The individuality which was required was not expressed through columns or balustrades, for the modular arrangement of the interior also affected the façade. The austerity of brick and the self-effacement of straight lines were not only suitable for the values that these Institutionists ${ }^{32}$ were seeking to establish, but they were also a novelty on the building scene of Madrid. To avoid an excessive increase in investment, the site would have to be on the outskirts of the city and the building would have to be modest, but they made a virtue out of necessity. First, because they wanted to differentiate clearly between an academic centre and a bourgeois palace and, secondly, because the promoters identified intellectual life with seclusion.

The place chosen to build the Students' Residence had many advantages: among them, its closeness to the Palace of Arts and Industry (first built as an Exhibition Pavillion, and later the location of a museum, several laboratories and an engineering school) and the fact that it was within the sphere of influence of the Racetrack, a place of recreation which attracted the urban elite. Later the elegance and modernity of the group would be reinforced by the construction of the colonies of rationalist villas of La Residencia and El Viso (Capitel, 1981): a further extension of the city strongly influenced by the designation for scientific installations of a hill, later to be known as the hill of Los Chopos (the Poplars), after it included a landscaping plan with 3000 poplars, following the principles of Arturo Soria that the town should be countrified and the country urbanised (AlonsoPereira, 1998; Torán, 1994). The Residencia was always far more than a

32 Institutionists were the supporters of the Institución Libre de Enseñanza (ILE) (Free Education Institution). They were trying to modernise Spain through an intellectual minority ready to renounce revolution, replacing it with the morality of science. From the ILE would come the idea of a para-university body devoted to research, and which would be embodied by the JAE in 1907 (Cacho-Viu. 1997). 
university college. Through courses, debates and lectures it guaranteed an education impossible to obtain elsewhere. It not only dealt with hitherto unheard of subjects, but it did it without the shabbiness of official academic life (Saenz de la Calzada, 1986). Architecture students were able to see Gropius, Le Corbusier or Lutyens, and science students could boast of having spent a few hours with Einstein or Madame Curie. In addition they installed some laboratories in which were to be written some of the most brilliant chapters of Spanish science (Laboratorios, 1934). On the ground floor of the fourth building erected, known as "El Transatlántico", ("The Liner"), were installed the histopathology, bacteriology, microanatomy and physiology labs. The Physiology laboratory directed by Juan Negrín ${ }^{33}$

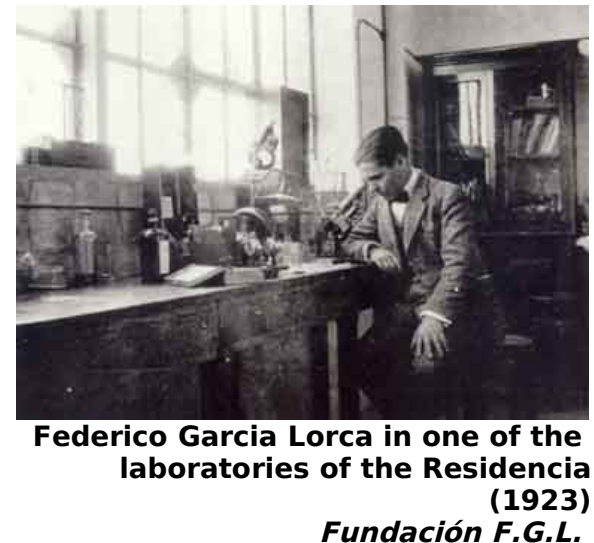

Fundación F.G.L.

\section{Vanguardists and the Residencia}

The number of residents in 1915 was about 150. Most of them were medical and engineering students attracted by the novelty of the laboratories and the neighbouring School of Industrial Engineers and Mines. But it also drew the future vanguard of art and

humanities: Jorge Guillén, Juan Ramón Jiménez (Nobel Prize for Literature, 1956), Federico García Lorca (see photo), Salvador Dalí, Luis Buñuel and Juan Gris. As well as many scientists among the visitors were H.G. Wells, W. Gropius, J.M. Keynes, P. Valery, M. Ravel and Marinetti.

The atmosphere was electric, and impressed a group of English visitors who found "Oxford and Cambridge combined in Madrid". occupied barely $100 \mathrm{~m}^{2}$ and yet there was room for a small library and a coffee corner. Pictures of these interiors cannot lie and, of course, there seems to have been no relationship between the cramped nature of the workplace and the ambition of its users, for those biologists were convinced of their mission as regenerators of the country.

We are always amazed by these problems of scale. Now, however, there is scorn for the utilitarian values which were sacrosanct a few decades before, and the gospel now preached is that of science for science's sake ${ }^{34}$. No one thinks of a University Hospital as a place to keep the patients suffering from the tumours which are under investigation: cancer is a scientific object which fits into the eyepiece of a microscope. The words and pictures describing it are as abstract as the

33 After studying with Theodor von Brücke in Leipzig, Juan Negrín (1892-1956) joined the Physiology Laboratory of the JAE. Throughout the twenties, Negrín combined his research work with academic management, having been appointed secretary of the Construction Board of the New University City of Madrid. A firmly committed republican, he became a member of the Spanish Socialist Workers' Party in 1929 and in 1937 would go on to become President of the Spanish government in the middle of the Civil War. After the defeat he would follow the way of other Spanish scientists and went into exile in Mexico (Barona, 1993). 34 The movement from utilitarian to fundamental science was described with great detail by Fox \& Guagnini (1999). MaCleod (1972 ) is still worthwhile. Also, for the public perception perspective in England see Turner (1980). And for France, Bensaude-Vincent (2000). 
laboratory where they are produced is impenetrable. Electrical engineering and the resistance of materials, or the processes of production or construction, the topics which dominated the engineering laboratories or the test laboratories of the army, were too far removed from the Residencia. Moreover, there is a tendency to see them as a matter for bureaucrats and politicians, since nothing excited this avant-garde more than, for example, Miguel Catalán's contribution to quantum physics with his discovery of multiplets at the beginning of the twenties (Sánchez-Ron, 1999: 232). It is not a matter of trying to make a value judgement on this vocation for pure science: what is important is to point out the tendency which seized hold of the hill of Los Chopos from 1910, the year of the construction of the Laboratorio de Investigaciones Físicas (Physics Research Laboratory) which was to be directed by Blas Cabrera. Internationalism was another of the forces dominating the policies of these laboratories, hence the emphasis in the programme on studying abroad or, later, the demands for better facilities which would be worthy of their work.

The consecration of this hub of activity would come in 1932 with the inauguration on the flat part of the campus of the new National Institute of Physics and Chemistry, known as the Rockefeller, equipped with facilities more in keeping with the times (Sánchez Ron \& Roca Rossell, 1993). The architects, Sánchez-Arcas and Lacasa, were chosen in order to bring the

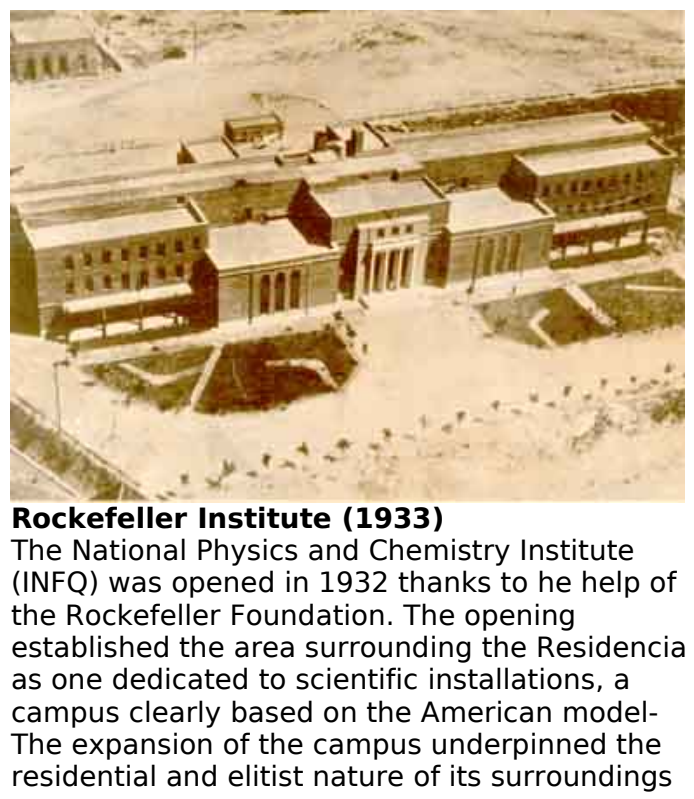

residential and elitist nature of its surroundings new principles of rationalist functionalism to the building (Bonet Correa, 1983). However, they did not fail to include in their design a huge doorway so that there would be room in the entrance for the scientist and his self-esteem. The novelty was neither in the layout nor in the elevation, but in the building techniques used. In the second decade of the twentieth century the change was not only one of architecture but also of cultures. The scientists who roamed the Chopos Hill paid homage to precision. Their undertaking was less local, less urban. The north campus chose the motto of science for science's sake, sharing with 
the artists and poets not only premises but also their enthusiasm for cosmopolitanism, abstraction and elitist culture.

And now let us look again at Madrid (see Full map). If we wish to see it all we shall have to stand on a watchtower. We have two, one at either end of the Castellana. To the south the intersection of Atocha, more of a maze than a traffic roundabout, dominated by the engineers who had used the city as a great experimental laboratory, giving it the straightforwardness of right angles, the vitality which comes with water, and a great quayside with departures to the ports of Bilbao, Barcelona, Lisbon and Valencia. To the north, the heights of the Racetrack, a Campus for people tired of struggling with noise and who seek the seclusion of the laboratory. Two worlds and two cities. Two ways of understanding science and two viewpoints from which to survey the city: one set among factories, the other amid open fields. A veritable symbol of the eclipse of one star and the emergence of another, for the scientists are the new heroes, summoned to replace the technicians.

\section{The dimensions of the experiment}

February $9^{\text {th }}, 1851$ was a memorable day for Madrid: the train reached Atocha for the first time, and with it the journalists extended their welcome to progress. No-one described it more expressively than Fernández de los Ríos when he saw in that mechanical convoy "...a monster which belched smoke, spread fire, and roared a hundred times more loudly than the lion in the Retiro zoo, [...] and ate up the distances faster than all the runaway mule trains of Fernando VII" (Fernández de los Ríos, 1876: 679-680). Indeed, he spared not one of the clichés which time and time again evoke the "technological sublime" experienced at the appearance of a locomotive (Nye, 1994; Lytvak, 1991). It is true that this first line owed a great deal to the tradition of the court's migrations to Aranjuez, and that in practice the company concentrated on the carriage of passengers, downgrading goods traffic. But it is none the less true that this was the most sensible route to the sea, since the Guadarrama mountain range made the northern journey inadvisable, and to the west lay a foreign coast. The construction was also an impressive undertaking: while at first there were 25 workmen, this figure rose to 6,000 nearer the time of the inauguration. The same can be said of the working capital (Fusi \& Palafox, 1997:65). But the number of 
passengers is the detail which best shows the change of scale, for the 690 carried in each of the three daily trains is incomparably more than the modest efficiency of stagecoaches.

When the connection to the Mediterranean Sea was completed, Cerdá loosed a torrent of his most exuberant prose: "the port of Alicante and the port of Valencia are now on the esplanade of Atocha; and within a couple of years there too will be the port of Barcelona" (Magrinyá, 1994: 282). His words were a crescendo which included Santander, Bilbao, Cadiz, Seville, Malaga and even Lisbon. Considering Atocha as a seaport was undoubtedly justified: Spain could at last boast a proper infrastructure and Madrid, once the court, would be a capital ${ }^{35}$. We could add more figures to confirm this optimistic view, but what is most important here is to emphasise the new complexity which gradually invaded the city by way of its "port". Take, for example, an innovation as complex as the construction of the $70 \mathrm{~km}$ section between El Escorial and Avila, in its passage over the Guadarrama. The undertaking, symbol and symptom of what we are discussing, had heroic overtones, for the lie of the land forced the construction of numerous cuttings and viaducts, as well as tunnels which in the case of Navalgrande bored through 993 metres of mountain. Its scale, comparable to the spirit of a war ${ }^{36}$, is evidenced by the 13,000 navvies engaged in the work, not to mention the sanitary and epidemiological problems the management of the undertaking had to face (Aguilar-Civera, 1988: 277).

But it was completed, and for Madrid 1858 would be an annus mirabilis. The connection to the sea was accompanied by the arrival of water. The old Arab system of water conduits now had a serious competitor. After several frustrated attempts, the project of the Civil engineers Juan Rafo and Juan Ribera, laid before Parliament in 1851, put an end to half a century of arguments, committees and reports and, of course,

35 There are many figures to support this belief. Here are some: as early as 185825,000 tons of goods had been taken out- wool, the main cargo, accounted for $15.08 \%$ of the totaland more than 156,000 tons brought in -coal (12.48\%) and building materials (9.94\%) heading the list. The line to the north, operating through to Irún from 1864, also grew rapidly and in 1866 carried 170,000 passengers out of Madrid as well as nearly 30,000 tons of goods (González Yanci, 1997).

36 The association with military ventures is not a mere metaphor. Railway companies frequently made use of military conscripts to make up for the shortage of manpower, especially at harvest time. To give some idea of the demand, it is enough to recall that between 1861 and 1863 an average of 50,000 labourers a day was employed on the construction of the railways in Spain (Comín, 1998: 119). Compare this with the 150,000 men who made up the Liberal army which put an end to the Carlist wars which ravaged Spain during the whole of the century. The other side had managed to raise 33,000 men (Fusi $y$ Palafox, 1997: 154). 
seemed to inaugurate a new age of fertility for a parched city in the middle of the bleak plateau of Castile (Gavira, 1997). But again it was worthwhile for the capital, for otherwise it would have been difficult to justify the enormous scale of work implied in bringing water from a dam built more than $70 \mathrm{kms}$ away. The hygienists spoke of the lack of cleanliness, and enthused at the prospect of copious liquid to wash the streets or to sow parks, but it was the engineers and the councillors who applauded the possibility of a source of energy to support agricultural and industrial production (Rafo \& Ribera, 1849: 3, 26-8).

Not only did rhetoric reach new heights of grandiloquence, but also the numbers became more immense. Suffice it to look at the figures of water consumption: the 3,000 $\mathrm{m}^{3}$ used daily till 1833, some 15 litres per person per day, rose to $32,599 \mathrm{~m}^{3}$, or about 90 litres for each inhabitant ${ }^{37}$. Just the construction of the Pontón de la Oliva dam employed 1,800 workers, of whom 1,500 were convicts. The writers of the Revista de Obras Públicas (Journal of Public Works), the official mouthpiece of the Civil engineers, thoroughly exploited the magic of these figures, and added many more: “... the total length of the dam is 78.80 metres. The total height of the upright part is 31.38 metres; this height is formed of 66 courses of masonry... the total thickness of this great structure at the base is 43.19 metres... the width of the dam at the coping is 6.96 metres". Here, obviously, these and many other mathematical algorithms were preached in order to convert all audiences (Martí, 1958). This explains why some newspapers, like El Museo Universal or La América, went so far as to publish dissertations prepared by engineers (Museo, 1858). They talked devoutly of mines, siphons, aqueducts, drains and pontoons, although true ecstasy was reserved for dams and reservoirs. We do not know how readers were trained to experience sublime emotion in the presence of such technical artefacts, but the fact is that the accounts exhausted all the available rhetorical effects, for the undertaking was treated as pharaonic and the adversities were biblical.

On the opening day, the reservoir, "a great heart from which lead the great arteries which are to bring new life to the population " (Olavarra, 1858: 11), was the scene for the first act of a mass extravaganza: "the roof

37 For the population of Madrid in 1858 of 250,000 inhabitants there was a surplus of nearly 10,000 cubic metres over what was needed to satisfy demand, calculated as an optimum of 90 litres per head. This oversupply was intended to provide for a forecast increase of 112,000 inhabitants. See Morer (1855: 148) and Hauser (1979: 280). 
of the reservoir", recount the writers of El Museo Universal, "converted into a delightful garden, displayed on all sides numerous trophies, a thousand times more glorious than those of weapons, created with exquisite taste from sights, levels, buckets, shovels, hoes, in short all those modest instruments of work which, wielded by the humble hands of the labourer crown the most gigantic works with success. Cheerful little flags placed at intervals and fluttering in the breeze seemed to summon the crowd to celebrate the triumph of science and of labour. And the people of Madrid did indeed come to see the arrival of the River Lozoya; there was never a potentate who received so enthusiastic a welcome, nor one who was so revered and honoured. The crowd occupied all the high places, and packed tight in the spacious Guards' parade ground." After the blessings of the Cardinal Archbishop of Toledo, with the presence of Queen Isabel II and her entourage, the scene moved off to the broad street of San Bernardo to witness the second act. The account tells of thousands of people packing the area, their gaze fixed on the simple fountain which had been constructed there. At a simple gesture from Lucio del Valle there shot up into the breeze “... a copious jet which rose to a height of ninety-odd feet among the cheers of the rejoicing crowd. A brilliant pure electric light shone through the water, which fell in a fine rippling spray". The festivities came to an end, but not the amazement, for people crowded round the watery monument all through that night and the days that followed. No-one in Madrid wanted to miss this landmark, whose frenzied welcome was seen as “... a vote of thanks to those who have done it so well" (Museo, 1858: 100-1). After the official festivity, 60 engineers from Madrid went off to the Cisne tavern to celebrate. And they were not sparing in their congratulations, boasting that they had brought the city up to the level of a European metropolis, while they drank toasts to those who "had so glorified their colleagues" (ROP, 1858: 154-5). The populace, then, while it was applauding the arrival of the water, also guaranteed the engineers' triumphal entry into the public arena.

The city witnessed the great challenge of turning itself into a space which would liberate all its communicative potential. It is not that stations changed the scale of traffic flows, but rather that they demanded a profound change in the city. And the engineer Ildefons Cerdá, indeed, was a visionary: “... together with a great quantity of merchandise, crowds of 
[railway] travellers of all sexes, ages and conditions came and went, like whole towns on the move, changing headlong from one home to another " (Cerdá, 1968: 6). Here is another great spectacle, but unlike the one presented for the arrival of the water, actors and spectators now blend without interruption. The ceremony they enact is both brilliant and routine, and it not only gives an account of the impact of locomotives, but also of their close connection with the masses. Following Cerdá, one would have to be blind not to realise that the overflowing of people into the streets called for the demolition of the city boundaries. The arrival of the train meant the opening-up of the city. And it still seems odd that the station should be known as an embarcadero, or landing-stage, a building which pictures show as rather too modest for the immensity of the effects which Cerdá mentions in his monumental work Teoría General de la Urbanización (General Theory of Urban Development). Here was his stroke of genius: to show the disproportion between the arrogance of machines and the smallness of man, for the brand-new engines penetrated into cities whose squalor was "the product of other, almost entirely passive, civilisations" (Cerdá, 1968: 7). So we are faced with the emergence of a new citizens' charter whose key point is mobility, and which despises as archaic the idea of the peasant rooted to his native ground. To accept his presence, raising him to the status of a historical subject, was to suppress any obstacle to his freedom of movement: it meant the destruction of barriers and the opening of avenues. "Destroy to advance" was the maxim of Cerdá and of all those engineers who followed Saint-Simon, able to translate social conflicts into technical problems. And the more progressive they were, the more technocratic. ${ }^{38}$ Fernández de los Ríos, acclaimed by Madrid's official historians as an unfairly neglected visionary, was undoubtedly an exceptional spokesman for this view. And as a man redolent of the "Gloriosa" of 1868, the revolution which ushered in the First Republic, as well as a typical participant of tertulias involved in public ventures, he was convinced that cities “....are no more than disorderly masses of men who live in perpetual motion and who are prepared to pay double if they find no obstructions or hindrances in the way of their production, trade, traffic or pleasure. Thus the city becomes a place to promote speed, which is the major manifestation of the new wealth liberated by the revolution" (Juliá, 1997: 424). Here is another more modern

38 Otter (2002) makes a similar refelction for liberalism in the late Victorian city. Instead of speed he stresses the value of vision, of clarity and translucence. 
and more abstract, almost futurist, formula for identifying demolition and progress, demanding an anonymous actor who would experience unexpected resonances between liberty and speed.

The railway and the water excited the reformists, giving them the ideal excuse to open up the sick body of old Madrid without restraint. ${ }^{39}$ And the engineers did not bat an eyelid when they tore up the maps and eliminated the narrow streets. Cerdá was to be the surgeon to test the urban viability of a city imprisoned in its own history. His method was simple, and the design clear: to start by identifying the centres which generated activity- Royal Palace, Ministries, Stock Exchange, markets and of course the central square of Puerta del Sol- and then to adapt the railway to fit the new urban plan. Or perhaps more accurately, to make the city fit the train. So his proposals to open up the dilapidated centre served to link all the planned thoroughfares with Atocha Station. The triangle of progress already had two tried and tested points: water and the train. The third would fall like a ripe fruit at the hands of the Royal Decree of April 1857, which imperiously ordered the expansion of the Capital. Railways, water and expansion were shown by the press as an obvious destiny. The battle for public opinion was won and a virtue was made of necessity. Our engineer now is Carlos María Castro, who had gained his fame with the Aranjuez railway. He had experience with the scalpel and now he had the chance to put into action a huge experiment which would transform the ramshackle old town into an exuberant city: "down with the Court and long live the Capital", it was another way to imagine the collapse of the monarchy and the birth of a nation. It was a huge task, but he only needed two hundred pages to argue that no change would be possible without first building that communications machine which we call a city (Castro, 1860).

And the apparent scarcity of means with which Castro expected to organise the people involved in such a vast experiment is really amazing. The work of levelling the city and its outskirts took no more than four months, and was carried out by six assistant engineers and some forty labourers (Frechilla, 1989: 128-9). Installed in his office (rented for the occasion in the central Calle León) with the plans on the table and assisted only by a single draughtsman and a secretary, Castro drew up roads,

39 The process of urban change we are describing was certainly not an exclusive of the Spanish capital. There is a huge litterature on the subject, namely for the cities of Paris (Picon, 1994; Caron,1990) and London (Porter, 1998; Owen, 1982). For an international overview see Tarr \& Dupuy (1988). See also Konvitz, Rose and Tarr (1990) 
planned space, defined dimensions, suggested an aesthetic and, finally, set the limits of a great design which gave centre stage to institutional buildings. But while he was preparing his proposals, he received the plan for the extension of Barcelona made by Cerdá, who understood that the drawings and proposals of the engineers had to be enriched by adding the principles of the hygienists. Only then did Castro bother to gather figures about the population of Madrid and to make forecasts of its future growth, supplementing the data which he could glean from the Manual de Madrid (1831) of Mesonero Romanos and the statistics in the Diccionario Geográfico (1847) of Madoz, with the information supplied by those in charge of hospitals and charity establishments. With these and other facts, like those referring to climatology from the Royal Observatory or those contained in the statistics of other European cities, Castro added to his original proposal an introduction which strengthened the links between health and cleanliness, or between town planning and public hygiene. But Cerdá's influence was not restricted to a purely cosmetic operation in order to justify the gigantic undertaking. The menacing presence of miasmas would be responsible for the redefinition of the orientation and width of the streets in order better to make use of the prevailing winds, as well as the rethinking of the characteristics of working-class housing. The layout of the city was no longer radial but was now squared off, aiming for a decentralised city in which there would co-exist different specialised areas. Seen on the map, there was simply no room for any more cleansing. The results are spectacular: the city is three times the size, and it all exudes the geometrical order so painstakingly set out in the drawings. They have managed to set out equidistantly and symmetrically squares with gardens, official and public buildings, luxurious residences with working-class areas, and industrial zones with agricultural land. Planimetry is overwhelming, and assigns a well-defined function to each zone: green spaces in the Retiro $(\mathrm{SE})$, factories in Chamberí (N), luxurious areas along the Castellana (E), middle class in the districts of Salamanca (NE) and Argüelles (NW), industry in Embajadores (SW), market gardens next to the River Manzanares (S) and, behind the Retiro (SE), housing for workers.

The city of Castro's dreams and the city spreading out from the focal point of Atocha towards the new water reservoirs in the northeast hoped to be very similar, but they were in a state of tension. Certainly, water and the 
railways were the pretext for the operation, but there was no agreement. In practice, they became the most disruptive elements of the new urban order that the engineers expected to forge in their plans. The new wave of public works spread throughout Spain, and floods of peasants arrived in Madrid in search of work. Construction was out of control: the capitals took no chances with expansion, while in the suburbs the city was spreading like an oil slick (Gavira, 1999). More worrying still would be the disorder reigning within Castro's grid plan. The growing demand for water imposed the building of a new reservoir, which interfered seriously with the planned geometry. This was indeed serious, but it was nothing compared to what was happening in the south since it had been decided to build the line connecting Atocha and Norte stations, for the presence of the railway converted the space between the river and the ring-roads into an area exclusively for industrial and railway use. In short, the impetus of industrialisation did not stop for the Castro plan ${ }^{40}$. But more than the railway line around the city, what was most important was the immense barrier which was built to the south, and which Castro condemned: “...it is a question of surrounding the capital of the kingdom, the great municipality of Madrid, with a belt of iron, and right inside the expansion zone!".

The discipline decreed by the engineers had to be fleshed out by the cleanliness preached by the hygienists. Madrid suffered the stigma of being the European capital with the densest population. It was obvious that this was a case of an unhealthy city, but the experts would only bow to the mystique of numbers, and argued that in 1857 each inhabitant of Madrid had hardly $8,25 \mathrm{~m}^{3}$ of air, a negligible figure compared to the $112,37 \mathrm{~m}^{3}$ enjoyed by a Londoner. And came so the moment of the doctors, and of course, they wasted no time in presenting themselves before the public. They came to talk about the miasma in the atmosphere, and to evaluate their dangerous effects. The mortality rates they published were appalling. It was not enough then to tidy up the land; the air had to be purged. The outlook was very gloomy, and Castro came down on the side of good sense.

40 Castro envisaged for this southern area a manufacturing zone serving to confirm the industrial tendency introduced by the nearby presence of the municipal abattoirs or the installation in 1846 of the Gasworks. However he never predicted the combining effects of railway lines and industry which led to an unstoppable dynamic. The best example is the Gasworks, belonging to Crédito Inmobiliario, a body which had obtained the concession for the Northern Railway to bring from Asturias the coal needed to produce gas. And with the mineral came new warehouses and more chemical factories, which justified the construction of the new nearby station of Peñuelas as a goods terminal. In 1880 came the inauguration of Delicias station to connect Madrid with Cáceres and Portugal, and in 1924 the completion of Peñuelas, not far from Imperial (Alvarez-Mora, 1980). 
His solutions adopted a technocratic tone which tempered the concealed Luddism of many hygienists, who showed more reverence for the prospect of a return to a pastoral Arcadia than enthusiasm for the Industrial Revolution (Urteaga, 1985: 398-9). The engineers saw the city as the new civilising environment, and scorned those other statistics which claimed lower mortality in the rural world. Here there arose another shift in public opinion, for hygienist rhetoric, which had always had a liberating image, came to be relegated to the position of an elitist and reactionary movement. Hygienism was then replaced by urbanism.

The change was evident in many fields. Hospitals, for example, changed their architecture to adapt to the new sanitary principles, as well as to reflect the power which medical specialities now had (Galison \& Thompson, 1999: 285). Indeed they stopped being the traditional house of shelter for foundlings, the needy or the underprivileged and began the search for an identity closer to what we would today call a health centre rather than a charity. The transition not only meant a more rational distribution of space, but it also affected the complete installations, being buildings equipped with real drainage systems, running water and a suitable separation of the areas devoted to kitchens, toilets and visitors' waitingrooms. Their structure followed an international standard which spread like wildfire and which developed along with the hygienist movement itself. From a rectangular area, functioning as a gallery to facilitate exterior communication there opened various cross wings which housed the specialised services. Between the lateral blocks there was an open space, normally with a garden, which assisted the isolation of the separate sections, and provided a recreation space for convalescent patients. In Spain it was Philip Hauser who most clearly formulated the guidelines to be followed by architects in order to achieve a building which should be a true "school of hygiene" (Hauser, 1979: 424). And he was not sparing in his recommendations: the floor had to be of linoleum to facilitate thorough cleaning, the building would be raised one or two metres above the ground on which it was built to allow ventilation and on a site of limestone which absorbed water, the windows had to occupy a third of the wall surface, and the wings could not house more than 30 or 40 patients in order to guarantee that each one had some $50 \mathrm{~m}^{3}$ of air and about $10 \mathrm{~m}^{2}$ of space. 
Each hospital distributed these wings in its own particular way. The Princesa Hospital, opened in 1857, was the first to follow these modern principles although, as Hauser declared, the patrons were not very generous with the land, and the architect could not surround the building with trees. The plan, however, shows four blocks on each side and the central services housed in a central section at the end of which is the church. The new model of hospital was undoubtedly justified by its efficiency. The separation of the patients was a measure in harmony with the importance then accorded to the theories of miasmic contagion and, moreover, smoothed the functioning of the building and the control of the patients. But we should not forget the unstoppable drift of medicine towards specialisation. The sections then not only improved the therapy, but they also lent legitimacy to areas of knowledge with dedicated areas of authority within the hospital prefiguring, years later, the division of university departments by speciality. Hospitals based on individual wings were a valid response to social demands and also to corporate pressures. And these were numerous, depending whether illnesses were divided up according to the organs of the body, by the age of the patients, or by the technology employed. Therefore, different specialities were demanding wards for surgery, or for gynaecology or paediatrics, or for microbiology, radiology, hydrotherapy, etc. Within the hospital there were also wards for pensioners (old people) or paupers, so that not only were illnesses classified but also the social origin of the patients. And all worked according to a highly successful plan: the larger the specialisation, the better care there was. To separate the patient from his environment and to isolate him in specialised blocks meant that the illness itself had to be segregated into its own area where it could be studied and perhaps cured. So hospitals became fully scientific institutions, with the peculiarity that the science was deployed in full view of the citizens, thus making the hospitals powerful instruments of positivist propaganda. Rather than infirmaries or sanatoriums, they became public temples of science.

Spanish medical historians have always given pride of place to the foundation of the Institute of Operating Techniques of Dr. Federico Rubio y Galí, as well as the Niño Jesús Hospital for children. And rightly so, since both faithfully reflect the changes we have been discussing. In 1880, the development of surgery compelled the Princesa Hospital to give up four 
wards to the surgeon Rubio y Galí. Soon, however, they proved too small, having to move to the area of La Moncloa, next to the very remote Santa Cristina Home and the Alfonso XIII Institute of Hygienics. In the new location, five small buildings made room for the specialities of Gynaecology, Urology, Cardiology and Ophthalmology, among others.

The Niño Jesús paediatric hospital, situated just behind the Retiro Park in the eastern fringe of the city, was founded in 1877, although its first section was not opened until December 1881. To this were added an orphanage block and another for infectious patients, as well as installations for electrotherapy, orthopaedics, surgery, dentistry and ophthalmology, as well as laboratories for histology and microbiology. The building had an area of more than 9,000 $\mathrm{m}^{2}$ and twelve blocks in a walled and landscaped area occupying nearly $30,000 \mathrm{~m}^{2}$. This laboratory-monument had an impressive façade which combined both the newest international medical architecture with Spanish historicist style, and it constituted the first cohesive element of the new district of Retiro (SE). Nowadays it is fully integrated into Madrid but at the turn of the century anyone looking around and trying to distinguish in the middle of those empty suburbs any other relevant building would only have found the new San Juan de Dios Hospital. As in the eighteenth century, science recovered its avant-garde role of showing the direction of Madrid's enlargement and the new scientific buildings assumed their destiny as architectural landmarks offering dignity to the capital.

The miasmic theories inspired the new hospital architecture, and they were also a familiar subject in the daily press. They formed part of the general ideology of the time and aroused much interest in public opinion. It hardly matters whether they were right or wrong: what is important is their extreme simplicity and propagandistic efficiency, for they enabled scientists to confront the city as an organic whole. But their very merits were their downfall. These ideas were so all-encompassing that they posed excessively complex problems. Their main drawback was not the lack of knowledge, but an excess of information and opinions. Miasma was everywhere, in the tainted air, in nauseating places or in rotting matter, and its corruptive power reached into every corner of the city. To tame this evil it was necessary to examine the city, and hitherto nobody had felt this need as urgently as the hygienist doctors (Corbin, 1986; Illich, 1989: 79). The city 
then achieved the status of a top-level object of scientific study. To track down the noxious vapours meant throwing open the doors of the whole city to the doctors, leaving not one nook or cranny hidden, for the effluvia reached markets, cemeteries, abattoirs, and sewers: that is, anywhere where there were people and especially any place subject to crowding, from theatres and churches to cafés, schools and barracks. We can make it clearer still by quoting the words written by P. F. Monlau, the prince of the nineteenth-century Spanish hygienists: "...society is one vast sanatorium" (Urteaga, 1985: 397). And that is where certainties end, for the fact is that diseases and treatments seemed to be arbitrary, appearing when they felt inclined and being cured without any pattern. Nobody was really sure why something happened here and not there, nor when to apply this or that prescription. Despite cordons sanitaires and quarantine, the outbreaks of epidemics continued to have catastrophic dimensions. In 1833 the first outbreak of cholera in Spain alone caused more than 100,000 deaths, a number which rises to 526,000 if we take into account the five outbreaks suffered during the whole century (Urteaga, 1985: 401).

Miasmic-atmospheric theories dominated the scene until the 1870's, when the work of two giants, Pasteur and Koch, got under way (Dagognet, 1994). Their success was directly proportional to the amount of public space formerly won by the hygienists. Beyond all doubt, without the pervading presence of the latter, it would be impossible to explain the impressive rise of these two nineteenth-century heroes. Two microbiologists who stemmed the tide at last provided a guide to the action which reduced the problem to the size of the laboratory. Pasteur showed scientists where they should concentrate their efforts (Latour, 1988b). It is not surprising that the first studies of microbiology in Spain should have been closely linked to the centres of histology, for not only did they house the defenders of "laboratory medicine", but they also possessed the majority of the microscopes. The pioneering groups gathered around the Madrid Biological Institute and the Theoretical and Practical School of Medicine and Surgery ${ }^{41}$. The former was in the private home of its founder Rafael Martínez Molina, who fitted out some micrographic and chemical laboratories in order to supplement official teaching with experimental

$41 \quad$ Both were born within the context of the Revolution of 1868. The First Republic approved the freedom of teaching, and managed to ratify a decree creating independent medical schools (López-Piñero, 1976: 248). 
methods. The Theoretical and Practical School was located in the General Hospital, one of whose wards was examined in 1872 by Federico Rubio and José Eugenio Olavide to check the asepsis of its atmosphere. The experiment has a well-deserved place in the annals of Spanish medicine and

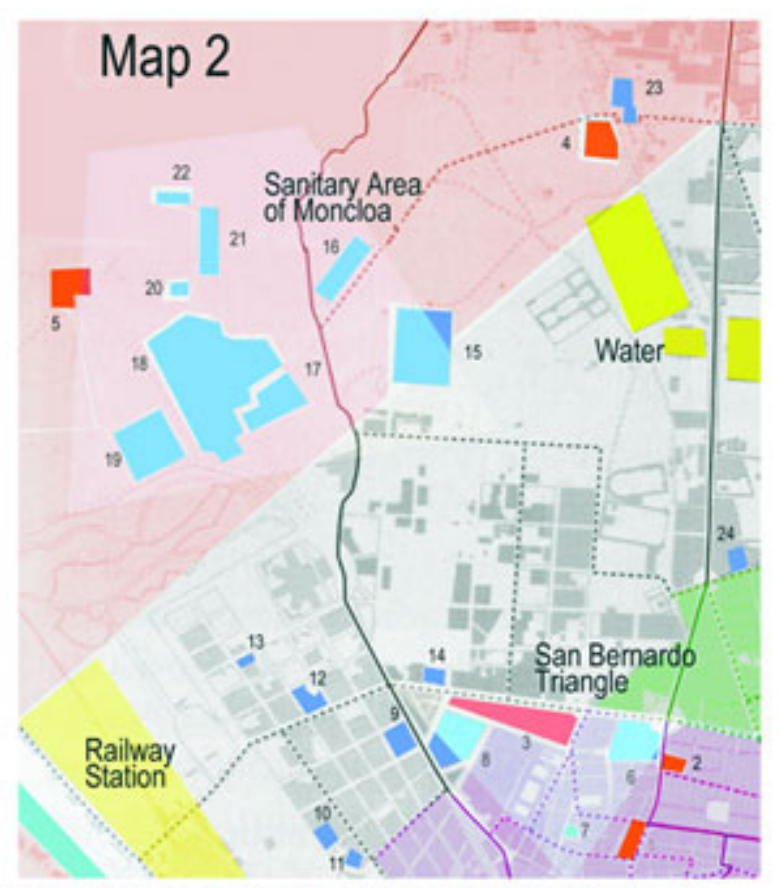

1 Universidad Central 2 Convento Salesas Nuevas 3 ICAI 4 Instiado Geografico 5 Escuela Agricultura

6 Hospital de la Pincesa 7 Hospital Jesis Nazareno 8 Hospital Milica

9 Hospital Buen Suceso 10 insthuo Sanidad Miltar 11 instbuto Microbiologico Lorente 12 Cuartel Sanidad Mirtar 13 Instituto Sueroterapia Alfonso XIII 14 Insthus Higiene Mital 15 Hosptal Clinico 16 Hospital Epidemicos 17 instituto Federico Rubio

18 Asilo Santa Cristina 19 insthuto de Higiene Alfonso XIII 20 Escuela Ondontologia

21 Facutad Medicina 22 Facultad de Farmacia 23 Hospital Craz Roja

24 Hospital Homeopático

From San Bernardo to Moncloa.

In 1897, after several years in the basement of the Princesa Hospital (6), the Rubio Institute (17) opened its new headquarters on the Moncloa heights. Its building, based on wards for each speciality (Urology, Cardiology, Ophthalmology, and Gynaecology) acted as a centre for teaching, medical care and research. Its location was exemplary: being next to the Santa Cristina Asylum (18) it heralded the inauguration of the future sanitary centre of la Moncloa, later completed by the Alfonso XIII Institute of Hygiene (19) and the future Hospital Clínico (15), as well as the faculties of Medicine (21), Pharmacy (22) and Dentistry (20). would have made Pasteur happy, not so much for its difficulty as for its significance as a clear sign of significant changes of mentality ${ }^{42}$. Histology was an experimental discipline which required modest facilities: a fact which, as the young Cajal recognised, was what made him decide to choose it as a speciality. Microbiology, on the other hand, always had boundless ambition, for its aim was to free the world of infection. So we are talking about an experimental discipline, but also one with a practical platform, since its scope spread to all social spheres. It was not enough to have good laboratories available. To gain prominence, that is to arouse interest in their proposals and raise resources for their research, microbiologists needed

the collaboration of other public frameworks ${ }^{43}$.

The hygienists' anxieties had been confirmed in 1871 with the setting-up of a State Vaccination Institute, under the auspices of the Royal

$42 \quad$ The Spanish Independent Practical School of Medicine and Surgery (Escuela Práctica Libre Española de Medicina y Cirugía), created by Pedro González Velasco in the building of the Anthropology Museum in Atocha, and the histopathology laboratory of the Princesa Hospital in San Bernardo should also be given credit for being the first institutions to accept the new bacteriology.

43 Jaime Ferrán, the most famous of Spanish bacteriologists, found himself caught up in a controversy in Valencia in which Cajal and Pasteur themselves intervened. It was the occasion of the 1885 cholera epidemic, when he was accused of trying to protect his profits in the production of the vaccine (López-Piñero, 1976: 250). 
Academy of Medicine, through its Vaccination Committee presided by Méndez Álvaro (Porras-Gallo, 1988). The origin of this institute can be attributed to the success reaped by the anti-smallpox vaccine in the FrancoPrussian War, and among its objectives was the conservation and study of the vaccine lymph, as well as vaccination itself. In 1872 began the inoculation of calves in order to cultivate and conserve the virus, and a part of the Madrid military garrison was inoculated. Two years later the number of inoculations reached the figure of 30,000 and its field of activity extended throughout Spain. While the numbers are considerable, the connection to the army cannot go unremarked, for this was an institution with resources and with a captive public to experiment on, which was vital to ensure the success of the venture. Another impressive fact: the staff of the Institute consisted only of five doctors to carry out the vaccinations, four nurses and three assistants (Guía, 1898: 84). So here was a peculiar organisation, capable of combining an excess of intentions with the greatest frugality of means. The disproportion is disturbing and is indicative of the new form that the science of the time was taking, for the size of the laboratory seems incompatible with the dimensions of the experiment.

The last decades of the nineteenth century saw a veritable epidemic of bacteriological laboratories in Madrid, which parallels the success in identifying the bacilli responsible for cholera, diphtheria, pneumonia, gonorrhoea or syphilis ${ }^{44}$. In 1899 the Alfonso XIII Institute of Serotherapy, Vaccination and Bacteriology was set up to bring some order into the scene. The operation meant redistributing power bases and finding a difficult balance between doctors, veterinary surgeons and pharmacists to win the battle for public opinion ${ }^{45}$. Only in the Alfonso XIII were the different

44 The speed with which these discoveries were made, one per year, guaranteed a golden age for bacteriology. Thus in 1894 the Central Institute of Bacteriology and Hygiene was created to produce and administer the anti-diphtheria serum of Roux and Behring. The Institute, dependant on the State Vaccination Institute for funding, never acquired its own premises, having as its base the histochemical and bacteriological laboratory of the San Juan de Dios Hospital. To administer the same anti-diphtheria serum- obtained from the Pasteur Institute in Paris- Vicente Llorente created in 1895 the Llorente Microbiological Institute. In 1883 private initiative also set up Doctor Balaguer's Vaccination Institute in the Plaza de Callao. The strategy of this centre- to advertise that all their vaccine lymph passed under the microscope of Ramón y Cajal before being administered- gained credibility, persuading the City Council in 1887 to entrust it with vaccination in all the first-aid medical centres. A good business which reached the not inconsiderable figure of 80,000 patients a year, and which continued to grow as the County Council designated vaccinator in the foundling hospital, homes and hospices, until in 1893 it obtained the monopoly which included prisoners and soldiers. See, Guía (1898)

45 Pharmacists and veterinary surgeons seemed to have a more active presence in the City Council, whose hygiene and cleanliness committee carried out inspections in markets, factories, dairies, boarding houses, taverns and colleges. In the Municipal Hygiene Laboratory, founded in 1877, all the work was restricted to the chemical analysis of drinks 
professional interests reconciled by means of a technical committee drawn from the three specialities. Ramón y Cajal, director of the Institute, was the person charged with negotiating peace, showing yet again his extraordinary ability to manage two apparently contradictory images: on the one hand, that of the ascetic shut away in his laboratory and on the other, the public figure always ready to take on the greatest responsibilities. The Institute lived modestly in rented premises until in 1908, two years after the award of the Nobel Prize to Cajal, they got approval for the construction of a building on a site in La Moncloa, on the outskirts in the extreme north-west of the city. From 1914, the year of the move, the Alfonso XIII was no longer only an excellent laboratory, but it had become a dynamic factory which in the twenties produced more than one and a half million doses of vaccine a year for the whole of Spain ${ }^{46}$.

Let us go back to the map of Madrid and look at the northwestern corner (see map 2). The location of the Alfonso XIII Institute in Moncloa reinforced the tendency for this frontier area to become a focus for health. Just in front of the Institute of Hygiene rose the blocks of the Santa Cristina Home and the Rubio Institute of Operative Medicine, all outside the boundary ditch designed in Castro's expansion,. Running just along the edge of the wall, at the same level, were the San Bernardo Home and the provisional facilities of the Epidemic Hospital. And in the area stretching from Moncloa to the reservoirs of the Canal of Isabel II, also running along the wall and adjoining the three northern cemeteries, were installed the Red Cross Hospital (1896) and the Maudes Hospital for labourers (1916). Further confirmation of this journey of science to the edges of the city: the new focus near Moncloa was replacing the triangle which had been formed in San Bernardo in the middle of the nineteenth century ${ }^{47}$. The institutions of military health round the Conde Duque barracks were now the only thing left in the triangle which in the fifties had enclosed the most promising talent of Spanish science. The evidence could hardly be clearer. The

and foodstuffs (Puerto-Sarmiento, 1983).

46 It was able to offer the whole spectrum of bacteriology, including anti-tetanus, antiplague or anti-anthrax serum, vaccines against flu, typhus or smallpox, as well as analysis of water, foodstuffs or medicines. The staff continued to grow, above all because of the great increase in demand during World War I, and in 1918 it had 25 doctors, a chemist, a vet and two medical assistants (Rodero, 1926).

47 And this movement towards the outskirts was not an intermittent trend. It is confirmed by the location of the other two major hospitals of Madrid created at the end of the nineteenth century, the new San Juan de Dios Hospital (1897) and the Niño Jesús Hospital (1885) in what was then the extreme east of the city, in the present district of Ibiza, where its only company was the station of the railway from Arganda. 
transfer of the Central University from San Bernardo to the site of the present University City had its origins in the Moncloa area's new status as a focus of health care. The first buildings to be completed were precisely those of medicine, pharmacy, dentistry and the Clinical Hospital. The construction of the University City would not only displace the triangle of San Bernardo but also the Atocha centre in which, since the eighteenth century, had been based the most important medical complex of the capital.

\section{From Café to Campus}

If we now try to look back at the distance covered by science and ourselves in the century with which we have been concerned, we have some conclusions to propose. Towards the third decade of the twentieth century scientific institutions had finished their peregrination. Although the civil war delayed the end of the journey, the fact is that three privileged areas have been established. In the Southeast, engineers have taken over Atocha, a setting from which they can overlook the principal nucleus of industrial activity of the city. Chopos Hill is already hinting at its future as an area for basic research, where the most sophisticated laboratories will be established, removed from any teaching function and far away from the university classrooms. If in Atocha the surroundings were clearly urban, even though it was separated from the bustle of the citizenry by its altitude and by the wall protecting it, at this other end of the Castellana we are in a precinct shared with other intellectuals belonging to the vanguard, and by buildings of a functional nature within a clearly residential setting. The third area of expansion will be the University City, more a suburb than a frontier, a zone designated for educational purposes rather than scientific. During their wanderings round the metropolis the scientists appear to have found their destiny in the culture of precision, which would mean abandoning the café as the principal venue for their activity. The transition was not easy, and called for much collaboration. Moreover, since each successive move was hailed with warmth by all those involved, we can only think that the journey had brought them to the right haven. First, because science now had its place in the city and therefore the scientists were beginning to feel that they were supported by a society which already knew where to locate them and perhaps the role to assign them. Second, because the shift to the edge of the metropolis not only had symbolic value, and to a certain extent 
expressed the type of contribution expected from them, it also implied the possibility of growing without further peregrinations; albeit at the price of accepting their limited centrality in politic or cultural debates, for it must be accepted that being away from the centre always consolidates some form of social control. To leave the café to go off to the campus was a gesture which implied two movements: the move from the centre to the periphery, and the change of an open space for a closed one. In the café, plans were always far too ambitious for the resources available. Nothing is more eloquent than the dimensions of the laboratory: in café culture the experiment spread throughout every corner of the city, while on the campus it was the problems of the city which had to be dissected so as to make experimental specimens which would fit inside an enclosed space.

In the Café culture which ruled academies, atheneums and universities, tertulias were crucial to knowledge organization. Improvised controversies, rhetorical effects and ornate discourses were seen as the best way to achieve consensus. These nowadays discredited practices shouldn't make us forget that the subjects discussed in such places could involve huge financial resources as well concern the welfare of the city inhabitants. And we should also remind us that it is always easier to go from the café table to the front page of newspapers than from ministerial offices to public works. Tertulia culture was an efficient way to agitate public opinion and to earn political relevance, however it was quite ineffective when it tried to answer concrete demands. So it is not surprising that the engineers who strove so hard to make a reputation as practical people accused university professors to be useless, speculative and rhetorical. Hygienists made a similar move when they abandoned newspapers and cafés for the new ecosystem of bacteriological laboratories, having replaced discourses about social welfare by microbiological wars. And academies are still fighting against their aristocratic birthmark while the Press was condemned for life for publishing unsound judgements and disdain rigor.

Before we finish, we still have a few lines to write about the visibility of science and of the city. What we have learnt about scientific practices can be summed up very briefly: they were activities which took shape around the city as problem, forming a conglomerate of disciplines less irrelevant and more public than traditional historiography normally records. The experts, all those engineers and doctors who wanted to be identified for 
their scientifically-based training, acquired political protagonism and unprecedented social visibility. But the metropolis was the object which was capable, on one hand, of reuniting the different specialities and of giving the disciplines a hierarchical structure following a different system of values. On the other hand, it was clear that some institutions would decline in the new environment, and that their future was debatable. The university, the charity hospitals and the academies were seen as a hindrance. The first because it never managed to forsake its ecclesiastic and pettifogging origins; the second because they were unable to shake off their charitable function and reclusive nature; and the third due to their courtly and aristocratic origins. The crisis towards which they drifted would be repeated and even today it is debatable, and indeed is debated, whether they are willing to be absorbed by the system of science and technology.

We also have something to say about the city. As we see how it was colonised by buildings, we think we are justified in confirming that the expansion of the city follows that of science. While we were following the movements of the scientists, we saw the metropolis emerge and mark out the journeys of both around the surrounding open country. And although we have not mentioned it before in this text, it is true that the evolution of this great experiment which transformed Madrid from a court into a Capital, required a great deal of knowledge of differential equations, spectroscopy or cell theory. Of course, our protagonists were scientists. But when we look for them through their academic texts they are hidden, either because they use technical jargon or because it is doubtful that they deserve a place in the history of discovery. It would be too hasty to conclude that they did not exist. But what we have said here is not only that there were such people, but also that they played a decisive role. Moreover, while we have been telling their story, we have encountered the city, and our story has certainly been that of a journey through Madrid; and while we wondered about periods and chronologies we have found ourselves among streets and suburbs. To see science we have had to cross the city, and to understand the city we have had to enter its laboratories. 


\section{References}

Aguilar-Civera (1988) Inmaculada Aguilar Civera, La Estación de Ferrocarril. Puerta de la Ciudad (Valencia: Generalitat Valenciana)

Aguilar-Civera, (1980) Inmaculada Aguilar-Civera, Pedro Navascués Palacio, Alberto Humanes Bustamante et al., Las estaciones ferroviarias de Madrid. Su arquitectura e incidencia en el desarrollo de la ciudad (Madrid: COAM)

Alonso-Pereira (1998) José R. Alonso-Pereira, La Ciudad Lineal de Madrid (Madrid: Fundación Caja de Arquitectos)

Alvarez-Mora (1980) A. Alvarez-Mora et al., 'Desarrollo histórico de la zona sur de Madrid', in I. Aguilar et al., Las estaciones ferroviarias de Madrid (Madrid: COAM): 147-205

Alvarez-Sierra (1966) José Alvarez Sierra, 'Las tertulias médicas de antaño: Cajal en los cafés madrileños', Anuario de Estudios Madrileños 1: 433-441

Ardwell (1972) Donald S.L. Ardwell, The organisation of science in England (London: Heinemann)

Alcaide González (1999a) Rafael Alcaide González, 'Las publicaciones sobre higienismo en España durante el período 1736 - 1939: un estudio bibliométrico', Scripta Nova. Revista Electrónica de Geografía y Ciencias Sociales 37, http://www.ub.es/geocrit/sn-37.htm.

Alcaide González (1999b) Rafael Alcaide González 'La introducción y el desarrollo del higienismo en España durante el siglo XIX. Precursores, continuadores y marco legal de un proyecto científico y social', Scripta Nova. Revista Electrónica de Geografía y Ciencias Sociales 50, http://www.ub.es/geocrit/sn-50.htm

Artola (1973) Miguel Artola, La burguesía revolucionaria (1808-1874) (Madrid: Alianza)

Baratas-Díaz (1996) Luis Alfredo Baratas-Díaz, ‘El núcleo de instituciones científicas matritenses en el Paseo del Prado desde el siglo XVIII', Asclepio, 48: 183-217

Baratas-Díaz (1997) Luis Alfredo Baratas-Díaz, Introducción y desarrollo de la biología experimental en España entre 1868 y 1936 (Madrid: CSIC)

Barles (1999) Sabine Barles, La Ville Délétère. Médecins et Ingénieurs dans l'Espace Urbain, XVIII - XIX Siècle (Champ Vallon: Seysell)

Barona (1993) José Luis Barona, 'J. Negrín y la modernización científica de España' Boletín de la Institución Libre de Enseñanza 18: 49-65.

Belhoste et al. (1995), B. Belhoste, A. Dahan Dalmenico, D. Pestre and A. Picon (eds.), La France des X: deux siècles d'histoire (Paris: Économica)

Bensaude-Vincent (2000), Bernadette Bensaude-Vincent, L'opinion publique et la science. À chacun son ignorance (Paris: Sanofi-Synthélabo)

Bensaude-Vincent \& Rasmussen (1997), Bernadette Bensaude-Vincent and A. Rasmussen (eds.), La science populaire dans la presse et l'édition, XIX et $X X^{e}$ siècles (Paris: CNRS Éditions)

Biagioli (1993), Mario Biagioli, Galileo Courtier (Chicago: Chicago University Press)

Bonet-Correa (1983) Antonio Bonet-Correa, 'El edificio Rockefeller', Arquitectura, 6: 69-72

Bonet-Correa (1989) Antonio Bonet-Correa in A. Fernández de los Ríos, El futuro Madrid, Ángel Fernández de los Ríos y la génesis del urbanismo contemporáneo (Barcelona: Los Libros de la Frontera)

Brockliss (2000) Laurence Brockliss, 'Gown and Town: The University and the City in Europe, 1200-2000', Minerva 38: 147-170

Broman (2002) Thomas H. Broman, "Introduction: Some Preliminary Considerations on Science and Civil Society", Osiris, 17 
Buck-Morss (1989) Susan Buck-Morss, The Dialectics of Seeing. Walter Benjamin and the Arcades Project (Cambridge, Mass.: MIT Press)

Cacho-Viu (1997) Vicente Cacho-Viu, Repensar el noventa y ocho (Madrid: Biblioteca Nueva)

Capitel (1981) Antón Capitel, ‘La construcción de la Colina de los Chopos de Madrid (de Antonio Flórez a Miguel Fisac)' Arquitectura, 52: 11-31

Caron (1990), François Caron et. al. Paris et ses Réseaux: naissance d'un mode de vie urbain, XIXe-XXe siècles (Paris: BHVP - Hôtel d'Angoulême Lamoignon)

Castro (1860) Carlos M. Castro, Memoria descriptiva del anteproyecto de ensanche de Madrid (Madrid: Imprenta de José C. De la Peña)

Capshew \& Rader (1992) James H. Capshew and Karen A. Rader, "Big Science: Price to the Present", Osiris, 7: 3-25.

Centenario (1977) Centenario de la Escuela de Minas de España: 1777-1877 (Madrid: ETSIM)

Cerdá (1968) Ildefons Cerdá, Teoría General de la Urbanización y aplicación de sus principios y doctrinas a la reforma y ensanche de Barcelona (Barcelona: Instituto de Estudios Fiscales)

Chastagnaret (1975) G. Chastagnaret, ‘Un ejemplo de revista científica: la Revista minera desde 1850 a 1914', in M. Tuñón de Lara, et al., Prensa y sociedad en España (1820-1936) (Madrid: Cuadernos para el Diálogo): 223-239.

Comín (1998) Francisco Comín, et al., 150 Años de Historia de los Ferrocarriles Españoles (Madrid: Anaya)

Corbin (1986), Alain Corbin, Le miasme et la jonquille: l'odorat et l'imaginaire social, $X V I I P^{e}-X I X^{e}$ siècles (Paris: Flammarion)

Cooter \& Pumfrey (1994) Roger Cooter and Stephen Pumfrey, 'Separate Spheres and Public Places: Reflections on the History of Science Popularization and Science in Popular Culture', History of Science, 32: 238-267

Dagognet (1994), François Dagognet, Pasteur sans la légende (Paris: Synthélabo)

Fernández de los Ríos (1876) A. Fernández de los Ríos, Guía de Madrid (Madrid) 679-680

Findlen (1993), Paula Findlen, 'Controlling the Experiment: Rethoric, Court Patronage, and the Experimental Method of Francesco Redi (1626-1697)', History of Science, 31: 35-64

Forgan \& Gooday (1996) Sophie Forgan, and Graeme Gooday, "Constructing South Kensington: the Buildings and Politics of T. H. Huxley's Working Environments." British Journal for the History of Science 29: 435-68.

Foucault (2001) Michel Foucault, 'Des espaces autres', Dits et Écrits II, 1976-1988 (Paris: Gallimard): 1571-1581

Fox \& Guagnini (1999) Robert Fox and Anna Guagnini, "Laboratories, workshops, and sites. Cocepts and prectices of research in industrial Europe, 1800-1914", Historical Studies in the Physical and Biologoical Sciences, 29: 63-294

Frechilla (1989) Javier Frechilla, La construcción del ensanche de Madrid, Madrid: ETSAM, unpublished doctoral thesis.

Fullaondo (1968) D. Fullaondo, 'Alberto de Palacio' Nueva Forma, 1968: 87-97

Fusi \& Palafox (1997) Juan Pablo Fusi y Jordi Palafox, España 1808-1996, el desafío de la modernidad (Madrid: Espasa Calpe)

Galison (1992) Peter Galison, 'The Many Faces of Big Science', in Peter Galison and Bruce Hevly (eds.), Big Science. The Growth of Large-Scale Research (Stanford: Stanford University Press.):1-17

Galison \& Thompson (1999) Peter Galison and Emily Thompson (eds.), The Architecture of Science (Cambridge, Massachussets: MIT Press)

Gavira (1997) Carmen Gavira, 'De la culture de l'eau à la technique hydraulique. Le Canal de Isabel II' in M. Marié, et al. (ed.), Cultures, usages et stratégies de l'eau en Mediterranée Occidentale. Tensions, conflits et régulations (Paris: L'Harmattan) 
Gavira (1999) Carmen Gavira, 'La ciudad y la no ciudad. Madrid 1567-1993', J. Gavira y C. Gavira, Madrid, centro y periferia (Madrid: Biblioteca Nueva)

Golinski (1998), Jan Golinski, Making Natural Knowledge: Constructivism and the History of Science (Cambridge: Cambridge University Press)

González Yanci (1997) M. P. Gonzalez Yanci, Los accesos ferroviarios a Madrid: su impacto en la geografía urbana de la ciudad (Madrid: CSIC)

Gooday (1998), Graeme Gooday, 'The premises of premises: Spatial issues in the historical contribution of laboratory credibility', in Crosbie Smith and John Agar (eds), Making Space for Science, (Houndmills: Macmillan), 216-245.

Guía (1898) Guía redactada con ocasión del IX congreso internacional de higiene y demografía (Madrid: Est. Tipográfico de Ricardo Fé)

Hamlin (1998) Christopher Hamlin, Public Health and Social Justice in the Age of Chadwick. Britain, 1800-1854 (Cambridge, Cambridge University Press)

Hannaway (1986), Owen Hannaway, 'Laboratory design and the aim of science: Andreas Libavius versus Tycho Brahe', Isis, Ixxvii (1986), 585-610.

Hauser (1979) Philip Hauser, Madrid bajo el punto de vista médico-social (Madrid: Editora Nacional)

Illich (1989) Ivan Illich, $\mathrm{H}_{2} \mathrm{O}$ y las aguas del olvido (Madrid: Cátedra)

Inkster (1997) lan Inkster, 'Science and Society in the Metroplis: a preliminary examination of the social and institutional context of the Askesian Society of London, 1796-1807', Annals of Science, 34: 1-32

Juliá (1997) Santos Juliá, 'Madrid, capital del Estado (1833-1993)', in Santos Juliá, David Ringrose and Cristina Segura, Madrid, Historia de una capital (Madrid: Alianza)

Kohler (2002) Robert E. Kohler, 'Place and Practice in Field Biology', History of Science, 40: 189-210

Konvitz, Rose, and Tarr (1990), Josef W. Konvitz, Mark H. Rose, and Joel A. Tarr, 'Technology and the City', Technology and Culture, 31: 284-294

Kranakis (1997), Eda Kranakis, Constructing a bridge: an exploration of engineering culture, design, and research in nineteenth-century France and America (Cambridge, Massachussets: MIT Press)

Laberge (2002) Ann Elizabeth Fowler La Berge, Mission and Method. The Early Nineteenth-Century French Public Health Movement (Cambridge: Cambridge University Press)

Laboratorios (1934) 'Los laboratorios de la Residencia', Residencia, 5: 26-30.

Lafuente (1998) Antonio Lafuente, Guía del Madrid científico. Ciencia y corte (Madrid: Doce Calles)

Lafuente \& López-Ocón (1996) Antonio Lafuente \& Leoncio López-Ocón, 'Tradiciones científicas y expediciones ilustradas en la América hispánica del siglo XVIII', in Juan José Saldaña, Historia social de las ciencias en América Latina (México D. F.: UNAM/Porrúa Ediciones): 247-282

Lafuente \& Peset (1988) Antonio Lafuente and José Luis Peset, ‘Las actividades e instituciones científicas en la España ilustrada', in Manuel Sellés, José Luis Peset y Antonio Lafuente (eds.), Carlos III y la ciencia de la Ilustración (Madrid: Alianza): 29-79.

Lafuente \& Saraiva (2001) Antonio Lafuente \& Tiago Saraiva, 'La OPA de la ciencia y la abducción de las humanidades', Claves de la Razón Práctica 112: 69-76

Lafuente \& Saraiva (2002) Antonio Lafuente \& Tiago Saraiva, Los públicos de la ciencia en España, siglos XVIII a XX (Madrid: fecyt)

Latour (1998) Bruno Latour, Paris, ville invisible (Paris: La Decouverte)

Latour (1988b) Bruno Latour, The Pasteurization of France (Cambridge: Harvard University Press)

Lefevbre (1974) Henri Lefevbre, La production de l' espace (Paris: Anthropos) 
López-Ocón (1997), Leoncio López-Ocón, ‘El fomento de la educación y de la ciencia en la sociedad española del sexenio democrático', Boletín de la Institución Libre de Enseñanza, 28-29: 127-148

López-Pînero (1976) José M. López-Piñero, Medicina moderna y sociedad española, siglo XVI-XIX (Valencia)

López-Pîñero (1992) José M. López-Pîñero (ed.) La ciencia en la España del siglo XIX (Madrid: Ayer, 7)

Litvak (1991) Lily Litvak, El tiempo de los trenes (Barcelona: Ediciones del Serbal)

MacLeod (2000), Roy Macleod (ed.), 'Nature and Empire', Osiris, 15

Magrinyá (1994) Francesc Magrinyá, 'La Teoría de la Viabilidad Urbana de Cerdá de 1861: un tratado sobre la reforma interior de las ciudades', Francesc Magrinyá \& Salvador Tarragó (eds...), Cerdá, ciudad y territorio, una visión de futuro (Barcelona: Electa), 1994, p. 282.

Martí (1858) V. Martí, 'Canal de Isabel II', Revista de Obras Públicas, 6 (17)

MaCleod (1972) Roy MaCleod, "Resources of Science in Victorian England: The Endowment of Science Movement, 1868-1900", in Peter Mathias ed., Science and Society (Cambridge: Cambridge University Press): 111-166

McClelland (1980) Charles E. McClelland, State, Society, and University in Germany 1700-1914 (Cambridge: Cambridge University Press)

McClellan III \& Regourd (2000), James E. McClellan III and François Regourd, 'The Colonial Machine: French Science and Colonization in the Ancien Régime', Osiris, 15: 31-50

Moran (1991) Bruce T. Moran (ed.), Patronage and Institutions: Science, Technology and Medicine at the European Court, 1500-1750 (Rochester, N.Y: Boydell Press)

Moreno-González (1988) Antonio Moreno-González, Una ciencia en cuarentena. La física académica en España (1750-1900) (Madrid: CSIC)

Morer (1855) José Morer, 'Canal de Isabel II, memoria del ante-proyecto de la distribución', Revista de Obras Públicas, 3 (13)

Museo (1858) 'Traída de aguas a Madrid' in El Museo Universal, 2: 12-13

Nadal (1975) Jordi Nadal, El fracaso de la industrialización en España, 1814-1913 (Barcelona: Ariel)

Navascués-Palacio (1973) Palacio Pedro Navascués-Palacio, Arquitectura y arquitectos madrileños del siglo XIX (Madrid: Instituto de Estudios Madrileños)

Nueva (1889) 'Nueva Escuela de Ingenieros de Caminos, Canales y Puertos', Revista de Obras Públicas, 7 (5): 78-80, 1889.

Nye (1994) David E. Nye, American Technological Sublime (Cambridge: MIT Press)

Olavarra (1858) Eugenio de Olavarra, 'Canal de Isabel II', in La América 9

Ophir, Shapin \& Shaffer (1991) Adi Ophir, Steven Shapin and Simon Shaffer (eds.), 'The Place of Knowledge: The Spatial Setting and its Relation to the Production of Knowledge', Science in Context, 4: 1

Otter (2002), Chris Otter, 'Making liberalism durable: vision and civility in the late Victorian city', Social History, 27: 1-15

Owen (1982), David Edward Owen, The Government of Victorian London, 1855-1899: The Metropolitan Board of Works, the Vestries and the City Corporation (Harvard University Press)

Picon (1992), Antoine Picon, L'Invention de l'ingénieur moderne: l'École des Ponts et Chaussées (1747-1851 (Paris: Presses de l'école nationale des ponts et chaussées)

Picon (1994), Antoine Picon, 'Les modèles de la Metropole. Les Polytechniciens et I'aménagement de Paris', in B. Belhoste, F. Masson and A. Picon (eds.), Le Paris des Polytechniciens. Des ingénieurs dans la ville (Paris: délégation à l'action artistique de la ville de Paris)

Porras-Gallo (1988) María I. Porras Gallo, 'Antecedentes y creación del Instituto de Sueroterapia, Vacunación y Bacteriología de Alfonso XIII', Dynamis, 18: 81-105 
Porter (1998), Dale H. Porter, The Thames Embankment: Environment, Technology, and Society in Victorian London (Akron, Ohio: University of Akron Press)

Puerto-Sarmiento (1983) Javier Puerto Sarmiento et al., 'El laboratorio Municipal de Madrid en el último tercio del siglo XIX', Dynamis, 3: 149-172.

Pyenson \& Sheets-Pyenson (1999) Lewis Pyenson and Susan Sheets-Pyenson, Servants of Nature, a History of Scientific Institutions, Enterprises and Sensibilities (London: Norton): 48-73

Rafo \& Ribera (1849) Juan Rafo \& Juan Ribera, Memoria sobre la conducción de aguas a Madrid (Madrid: Imprenta de La Publicidad)

Ramón y Cajal (1984) Santiago Ramón y Cajal, Historia de mi labor científica (Madrid: Alianza)

Repullés-Vargas (1897) Enrique Repullés-Vargas, Escuela de Ingenieros de Minas y Laboratorios Gómez Pardo (Madrid: Imprenta del Asilo de Huérfanos)

Reseña (1914) 'Reseña de los principales establecimientos científicos y laboratorios de investigación de Madrid', [Proceedings of the] IV Congreso Asociación Española para el progreso de las Ciencias (Madrid: AEPC)

Rodero (1926) Lorenzo Rodero, 'El Instituto Nacional de Higiene de Alfonso XIII', in La Esfera 635: 18-19

ROP (1858) Revista de Obras Públicas, 6 (13)

Rodríguez-Quiroga ( 2001) Alfredo Rodríguez-Quiroga, 'Las relaciones de Santiago Ramón y Cajal con la comunidad neurohistológica internacional', Boletín Institución Libre de Enseñanza, 40-41 (February 2001)

Romeu de Armas (1990) Antonio Romeu de Armas, El Real Gabinete de Máquinas del Buen Retiro (Madrid: Fundación Juanelo Turriano)

Russell (1983) Colin Russell, Science and Social Change, 1700-1900 (McMillan Press)

Sáenz de la Calzada (1986) M. Sáenz de la Calzada, La Residencia de Estudiantes (1910-1936) (Madrid: CSIC)

Sáenz-Ridruejo (1993) Fernando Sáenz-Ridruejo, Los ingenieros de caminos (Madrid, Colegio de Ingenieros de Caminos, Canales y Puertos)

Sambricio (1998) Carlos Sambricio, Territorio y ciudad en la España de la llustración (Madrid: MOPT)

Sánchez-Ron (1988) José Manuel Sánchez-Ron (ed.) La Junta para la Ampliación de Estudios e Investigaciones Científicas 80 años después (Madrid: CSIC)

Sánchez-Ron (1999) José Manuel Sánchez-Ron, Cincel, martillo y piedra. Historia de la ciencia en España (Siglo XIX y XX) (Madrid: Taurus)

Sánchez-Ron \& Roca Rossell (1993) José M. Sánchez Ron and Antonio Roca Rosell, 'Spain's First School of Physics: Blas Cabrera's Laboratorio de Investigaciones Físicas' Osiris, 8: 127-155

Shapin (1988), Steven Shapin, 'The House of Experiment in Seventeenth-Century England', Isis, 79: 373-404

Sheets-Pyenson (1985), Susan Sheets-Pyenson, 'Popular Science periodicals in Paris and IOndon: the emergence of a low scientific culture, 1820-1875', Annals of Science, 42: 549-572.

Shinn (1979) T. Shinn, 'The French Faculty System, 1808-1914, 1808-1914', Historical Studies in the Physical Sciences, 10: 271-333

Tarr \& Dupuy (1988), Joel A. Tarr and Gabriel Dupuy, The Rise of the Networked City in Europe and America (Philadelphia: Temple University Press)

Torán (1994) Eva Hurtado Torán, 'Del Cerro del Viento a la Colina de los Chopos', Arquitectura, 297: 66-74.

Torroja-Menéndez (1995) José Ma Torroja-Menéndez, ‘Los ingenieros en la RACEF y RACEFN de Madrid', in P. García Barreno et al., La Real Academia de Ciencias 1582-1995 (Madrid: RACEFN): 385-429

Turner (1980) Frank Turner, "Public Science in Britain, 1880-1919" Isis 71: 589-608. 
Urteaga (1985) Luis Urteaga, 'El pensamiento higienista y la ciudad: la obra de P.F. Monlau', in Antonio Bonet Correa (ed.) Urbanismo e historia urbana en el mundo Hispano (Madrid: Universidad Complutense): 397-412

Urteaga \& Nadal (2001) Luis Urteaga y Francesc Nadal, Las series del mapa topográfico de España a escala 1:50.000 (Madrid: Ministerio de Fomento): 17-47.

Velázquez Bosco (1990) Ricardo Velázquez Bosco, (Madrid: Dirección General de Bellas Artes y Archivos)

Villacorta-Baños (1985) Francisco Villacorta-Baños, El Ateneo Científico, Literario y Artístico de Madrid (1885-1912) (Madrid: CSIC)

Walters (1997) Alice N. Walters, 'Conversation Pieces: Science and Politeness in Eighteenth-Century England', History of Science, 35: 121-154

Westfall (2003) Catherine Westfall, 'Rethinking Big Science. Modest, Mezzo, Grand Science and the Development of the Bevalac, 1971-1993', Isis, 94: 30-56 